\title{
Toxicity evaluation of collagen hydrolysates from chrome shavings and their potential use in the preparation of amino acid fertilizer for crop growth
}

\author{
Li Zhao ${ }^{1,2}$, Shengdong $\mathrm{Mu}^{1,2}$, Weixiang Wang ${ }^{3 *}$ and Haibin $\mathrm{Gu}^{1,2^{*}}$
}

\begin{abstract}
Resource utilization of chrome shavings (CS) has attracted a lot of attention from scientists and technologists in leather industry. Especially, the collagen hydrolysates extracted from CS are expected to find potential application values in agricultural field. However, there is no biotoxicity analysis of collagen hydrolysates from CS. Herein, the collagen hydrolysates with different molecular weights were produced from CS by three hydrolysis dechroming methods including alkaline hydrolysis, enzymatic hydrolysis and alkaline-enzymatic synergistic hydrolysis, and the optimal hydrolysis process of CS was designed and conducted. To evaluate their toxicity, the three collagen hydrolysates were formulated into a nutrient solution for zebrafish development. The obtained results indicated that the hydrolysates with low concentrations (less than $0.6 \mathrm{mg} / \mathrm{mL}$ ) were safe and could promote the development for zebrafish embryos. Furthermore, the three collagen hydrolysates were utilized as organic nitrogen sources and formulated into amino acid water-soluble fertilizers (AAWSF) including alkaline type fertilizer $(\mathrm{OH})$, enzymatic type fertilizer $(\mathrm{M})$ and alkalineenzymatic type fertilizer ( $\mathrm{OH}-\mathrm{M})$ for the early soilless seeding cultivation of wheat, soybean and rapeseed. It is worth mentioning that the chromium contents in the prepared AAWSF were less than $10 \mathrm{mg} / \mathrm{kg}$, which is far less than the limit value in the standard (China, $50 \mathrm{mg} / \mathrm{kg}$ ). The growth and development of seedlings (germination rate, plant height, fresh weight of leaves, soluble sugar content and chlorophyll content) were investigated. The corresponding results showed that the growth of seedlings watered with AAWSF was better compared with the other treatments, and the $\mathrm{OH}-\mathrm{M}$ fertilizer had the best promoting effect on the seedlings growth and development, followed by the $\mathrm{M}$ and $\mathrm{OH}$ fertilizers. The safe toxicity assessment of the collagen hydrolysates will expand their application scope, and the use of collagen hydrolysates extracted from CS for seedlings growth also provides an effective and reasonable way to deal with the chromium-containing leather solid waste, which is an effective way to realize its resource utilization.
\end{abstract}

Keywords: Chrome shavings, Collagen hydrolysate, Zebrafish, Toxicity evaluation, Amino acid water-soluble fertilizer, Seedling growth

\footnotetext{
*Correspondence: wang_weixiang@hotmail.com; guhaibinkong@126.com

${ }^{1}$ Key Laboratory of Leather Chemistry and Engineering of Ministry

of Education, Sichuan University, Chengdu 610065, China

${ }^{3}$ College of Food and Bioengineering, Xihua University, Chengdu 610039,

China

Full list of author information is available at the end of the article
} 


\section{Graphical Abstract}

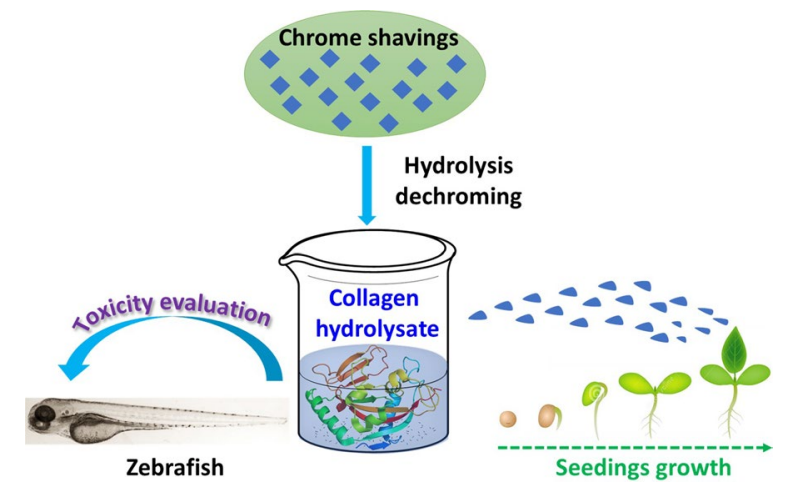

\section{Introduction}

Past decades have witnessed the rapid development of the leather industry. It was reported that approximately 18 billion square feet of leather was produced each year, and $90 \%$ of them was tanned by chrome [1]. In tanneries, according to the sample requirements, splitting, shaving, and trimming operations are often conducted. As a result, various chromium-containing leather solid wastes involving chrome shavings (CS) are yielded. In the CS, chromium exists as the trivalent form, which is nontoxic, but it is possible to be oxidized to chromium (VI) that is a highly toxic substance to the human body and environment $[2,3]$. Thus, CS has been classified as a hazardous pollutant in many countries. Additionally, statistics showed that CS has been generated about 0.8 million tons in the world every year [4]. Such a large number indicates that the problem of environmental pollution brought by CS is a thorny issue and challenge for the world, especially for the big countries in leather industry, such as India, China and Brazil. In the early days, the most common way to treat CS is the direct landfill $[5,6]$. But it faces a second pollution problem to the environment because of the diffusion of chromium leachate from CS. Next, as an alternative, the incineration method was presented and used [7], whereas it leads to the wasting of high-valuable resources (e.g. collagen) in CS.

CS mainly contains $90 \%$ collagen, indicating that CS is a valuable resource. Therefore, it is particularly important and meaningful to recycle collagen in CS, resulting in the utilization of collagen. To achieve this goal, it is necessary to separate the chromium from CS, and the collagen source is obtained. Currently, oxidation, hydrolysis and the combination methods have been proposed and investigated. Compared with oxidation dechroming approach, hydrolysis dechroming methods are considered as environmentally friendly programs $[8$, 9]. Hydrolysis dechroming methods can be divided into four typical types including acidic hydrolysis dechroming [10], alkaline hydrolysis dechroming [11], enzymatic hydrolysis dechroming [12] and the combination of two or several dechroming methods [13, 14]. However, there is no guarantee that all the chromium can be removed in all the dechroming protocols. The residual chromium in collagen hydrolysates could pose a threat to human beings and the environment. Thus, the toxicity evaluation of the collagen hydrolysates from CS is very significant. Zebrafish has been regarded as a great animal model for biological toxicity evaluation because its organs and tissues have been considered the same as human $(87 \%$ of similarity) in terms of anatomy, physiology or molecular level [15-18]. So far, there is no report on the biosafety evaluation of CS collagen hydrolysate using zebrafish as an animal receptor.

Meanwhile, collagen hydrolysate possesses abundant amino acids that can be used as organic nitrogen and carbon sources to prepare amino acid fertilizer for the nursery of crops [19,20]. Amino acids can be directly absorbed by crops, eliminate active free radicals in the body [21], stimulate crops growth, promote crops metabolism, increase crops yields, improve crops quality and enhance crops disease resistance [22-28]. For example, Pang et al. [29] investigated the effect of amino acid fertilizer from cottonseed meal on the growth and development of wheat compared with sprayed water and commercial amino acid water-soluble fertilizer (AAWSF). The results revealed that the plant height, leaf size, chlorophyll content and dry material of wheat were increased, and the wheat tillering as well as earing were increased, too, when they were treated with the amino acid fertilizer from cottonseed meal. On the other hand, amino acids can form a large amount of colloids in the soil, which is conducive to the retention of water and fertilizer. In addition to this, the large amount of amino and carboxyl groups in amino acids can give the soil a 
certain buffering performance, which can resist the acidbase change of the soil, and will not pollute the environment [23]. Therefore, the collagen hydrolysate from CS is expected to have great resource utilization value in agriculture, especially for crop planting.

Herein, CS was treated by three hydrolysis dechroming methods (alkaline, enzymatic and alkaline-enzyme synergistic methods) to get three collagen hydrolysates with different molecular weight (MW). Taking protein content as the evaluation index, the optimal treatment process of each method was determined by optimizing the hydrolysis dechroming parameters. Then, the toxicity of the three collagen hydrolysates was analyzed and evaluated by using them as the nutrient solutions for the development of zebrafish embryos. The hatchability, mortality, deformity, body length, pericardial area and $20 \mathrm{~s}$ heartbeats of zebrafish embryos were recorded at different exposure time. Finally, these collagen hydrolysates were utilized to formulate different types of AAWSF for the germination and growth of three types of crops (wheat, soybean and rapeseed) in the early stage. The germination rate, plant height, fresh leaves weight, nitrogen $(\mathrm{N})$, phosphorus $(\mathrm{P})$, potassium $(\mathrm{K})$, soluble sugar and chlorophyll contents were determined to estimate the efficiency of the fertilizers containing collagen hydrolysates with different MW.

\section{Experimental}

\subsection{Materials}

CS was provided by the pilot plant of the department of biomass and leather engineering. AB-type zebrafishes were gratefully gifted from State Key Lab of Biotherapy, Sichuan University. Wheat (Changfeng 2112), rapeseed seeds (Qin You 13) and Soybean (Golden bean 99) were purchased from Shaanxi Changfeng Seed Industry Co., Ltd. All the other chemicals were from commercial sources and used as received.

\subsection{Preparation of collagen hydrolysate}

\subsubsection{General alkaline hydrolysis dechroming method}

In the alkaline hydrolysis method, $\mathrm{NaOH}$ was used to extract the collagen hydrolysate from CS. Briefly, CS $(2 \mathrm{~g})$ was suspended in water $(40 \mathrm{~mL})$ containing a certain amount of $\mathrm{NaOH}$ and digested for a desired time at different temperature. When the temperature was cooled to room temperature, the mixture was filtered with gauze (500 meshes) to collect the filtrate. The filtrate was then centrifuged at $8000 \mathrm{r} / \mathrm{min}$ for $8 \mathrm{~min}$ to obtain the supernatant. Finally, the alkaline collagen hydrolysate $(\mathrm{ACH})$ as a power product was yielded by the lyophilization of the supernatant.

\subsubsection{General enzymatic hydrolysis method}

In the enzymatic method, 1398 neutral protease was used to extract the collagen hydrolysate from CS. Briefly, CS $(2 \mathrm{~g})$ was first suspended in deionized water $(40 \mathrm{~mL})$ and the $\mathrm{pH}$ of solution was adjusted to 8-9. After that, 1398 neutral protease (enzyme activity: 50,000 u/g) was added and the mixture was stirred for a desired time at different temperature. Subsequent experiments were the same as the above alkaline hydrolysis method. And the enzymatic collagen hydrolysate $(\mathrm{ECH})$ was generated.

\subsubsection{General alkaline-enzymatic hydrolysis method}

The CS were firstly hydrolyzed by the alkaline method and followed by the enzymatic hydrolysis method. The hydrolysis conditions of the alkaline-enzymatic hydrolysis method were the optimal hydrolysis conditions of the above alkaline and enzymatic hydrolysis methods. And the alkaline-enzymatic collagen hydrolysate $(\mathrm{AECH})$ was obtained as a power product.

\subsection{Analysis of collagen hydrolysate}

\subsubsection{Heavy metal content}

The contents of heavy metals in the hydrolysate were determined as follows: the sample $(1.0 \mathrm{~g})$ was added into the concentrated nitric acid-hydrogen peroxide mixture solution (concentrated nitric acid: hydrogen peroxide $=3: 1, \mathrm{v} / \mathrm{v}, 20 \mathrm{~mL}$ ) and then digested for two times upon slowly heating. After the digesting process, the mixture was cooled to room temperature and diluted to $100 \mathrm{~mL}$ with distilled water. Finally, the heavy metal contents (chromium $(\mathrm{Cr})$, mercury $(\mathrm{Hg})$, arsenic (As), cadmium $(\mathrm{Cd})$ and plumbum $(\mathrm{Pb})$ ) were determined by the inductively coupled plasma emission spectroscopy (ICP, Perkin Elymer USA, Optima800).

\subsubsection{MW}

The MW of the obtained hydrolysate was characterized by two methods including sodium dodecyl sulphatepolyacrylamide gel electrophoresis (SDS-PAGE) and gel permeation chromatography (GPC). The SDS-PAGE measurements were conducted based on a reported method with a slight modification [30]. Briefly, resolving gel $(18 \% \mathrm{~T}, 5 \% \mathrm{C})$ and stacking gel $(5 \% \mathrm{~T}, 3.3 \% \mathrm{C})$ were prepared for standby. Samples (including marker and experimental samples) were mixed with $1 \mathrm{M}$ Tris$\mathrm{HCl}$ buffer (24\% glycerol, 8\% sodium dodecyl sulfate (SDS), and $4 \% \beta$-mercaptoethanol, $0.02 \%$ Coomassie Brilliant Blue G-250, pH 6.8) and then boiled for $5 \mathrm{~min}$. The resulting sample $(15 \mu \mathrm{L})$ was injected into gel wells and run for approx. $3 \mathrm{~h}$ at $150 \mathrm{~V}$. After that, the gel was stained with Coomassie Brilliant Blue G-250 (0.25\%)/glacial acetic acid (10\%)/methanol solution (45\%), and then 
de-stained with acetic acid (10\%) until the bands were clear. Finally, the gel plate was observed and analyzed by gel imager (Bio-Rad Co., Ltd, GelDoc XR+). GPC measurements were conducted in aqueous solution of sodium azide $\left(\mathrm{NaN}_{3}\right)$ using Shimadzu high performance liquid chromatography (HPLC) system equipped with PLgel $5 \mu \mathrm{m}$ MIXED-D columns, refractometric and UV detectors, column oven and integrated degasser. Polymer molecular weights were calculated based on the multiangle light scattering data using the Wyatt Astra software, with $\mathrm{dn} / \mathrm{dc}$ values of the polymers determined from the RI detector using Astra. Column calibration was performed using polyethylene oxide (PEO) standards from Polymer Laboratories.

The analysis methods of the other parameters including protein content, ash content, and $\mathrm{pH}$ value were described in detail in the supporting information (SI).

\subsection{Zebrafish husbandry and embryos collection}

Zebrafish husbandry work and the preparation of the nutrient solution containing collagen hydrolysate were described in the SI.

Before the beginning of the embryos collection experiment, the healthy adult zebrafish (the male to female ratio was 2:1) should be selected and placed in a separate mating box until the day before breeding. In order to separate male and female zebrafishes, the middle of the mating box was separated by a baffle. And the mating box containing zebrafishes was placed in a dark incubator at $28.5^{\circ} \mathrm{C}$ for breeding. $12 \mathrm{~h}$ afterward, the mating box was taken out and the baffle was removed to let the male and female zebrafishes begin to mate and lay eggs for $30 \mathrm{~min}$. Then, the eggs were washed with distilled water, and inspected under a stereomicroscope (SZX10, Olympus, Japan) to select the uniformly divided and healthy embryos with a smooth surface for the subsequent experiments. The finally obtained embryos were cultivated in embryo culture medium at $2 \mathrm{~h}$ post-fertilization (hpf). The authors certify that all the experiments on live animals comply with the relevant laws, and the institutional committee of Sichuan University approved our experiments.

\subsection{Embryonic acute toxicity test}

According to "the Organization for Economic Cooperation and Development (OECD) guidelines [31], the embryonic/larvae toxicity test was carried out. The healthy embryos cultured for $2 \mathrm{hpf}$ were chosen and put into a 6-well plate, and each plate contained thirty embryos. The embryos culture medium containing collagen hydrolysate $(5 \mathrm{~mL})$ was added and the embryos were cultivated in a calorstat $\left(28.5{ }^{\circ} \mathrm{C}\right)$. The embryos cultured with the embryos culture medium were labeled as Blank.
At $24 \mathrm{hpf}, 48 \mathrm{hpf}, 72 \mathrm{hpf}$ and $96 \mathrm{hpf}$, the mortality, hatchability, deformity, body length, pericardial area and $20 \mathrm{~s}$ heartbeats of the embryos were observed and recorded. The hatchability represented the ratio of the number of hatched embryos in the experimental group to the number of hatched embryos in the blank group. The mortality was expressed as the percentage of the total number of dead embryos to the total number of embryos. The body length and pericardial area of embryos were measured by Scopephoto software (Chengdu Jingcheng Co., Ltd, China).

\subsection{Preparation of AAWSF}

During the preparation process of AAWSF, the collagen hydrolysates, calcium phosphate and potassium chloride were used as N, P and K source, respectively, to prepare the three kinds of AAWSF including alkaline type fertilizer $(\mathrm{OH})$, enzymatic type fertilizer $(\mathrm{M})$ and alkaline-enzymatic type fertilizer $(\mathrm{OH}-\mathrm{M})$. The contents of the corresponding collagen hydrolysates $(\mathrm{ACH}, \mathrm{ECH}$ and $\mathrm{AECH}$ ) in the $\mathrm{OH}, \mathrm{M}$ and $\mathrm{OH}-\mathrm{M}$ were 121,114 and $107 \mathrm{mg}$, respectively (the volume of distilled water used was $100 \mathrm{~mL}$ ). The dosages of calcium phosphate and potassium chloride in each fertilizer were 13.4 and $6.4 \mathrm{mg}$, respectively. For the comparison, the tap water without $\mathrm{N}$ source and the organic fertilizer using urea (32.2 $\mathrm{mg}$ ) as $\mathrm{N}$ source were prepared, and the addition amounts of $\mathrm{P}$ and $\mathrm{K}$ sources were the same as AAWSF. The former and later were named as $\mathrm{CK}$ and OF, respectively. The detailed nutrient usage of each fertilizer was described in Additional file 1: Table S7.

\subsection{Analysis of AAWSF}

\subsubsection{Heavy metal content}

Fertilizer $(1.0 \mathrm{~g})$ was added into the digestion solution of concentrated $\mathrm{HNO}_{3}$ and $\mathrm{H}_{2} \mathrm{O}_{2}$ with a ratio of $3: 1(20 \mathrm{~mL})$, heated and digested. After the digestion, the solution was cooled to room temperature and diluted to $100 \mathrm{~mL}$ with distilled water in a volumetric flask. The contents of $\mathrm{Cr}$, $\mathrm{Hg}$, As, $\mathrm{Cd}$ and $\mathrm{Pb}$ in the obtained solution were analyzed by ICP.

\subsubsection{Insoluble substance content [32]}

Fertilizer $(10.0 \mathrm{~g})$ was added into distilled water $(250 \mathrm{~mL})$, stirred for $3 \mathrm{~min}$, placed for $5 \mathrm{~min}$ and filtered to obtain the residue. The resultant residue was dried for $1 \mathrm{~h}$ at $110{ }^{\circ} \mathrm{C}$, and cooled to room temperature in a dryer. The dried residue was finally weighed.

\subsection{3 $\mathrm{pH}$}

The $\mathrm{pH}$ value was determined using a $\mathrm{pH}$ meter (METTLER TOLEDO Co., Ltd., FE28). 


\subsection{Crops seeding and growth experiments}

Seedlings growth was carried out through the hydroponic culture method. The crops growth experiments were conducted in the following steps: Firstly, wheat (100 grains), soybean (50 grains) and rapeseed seeds (100 grains) were immersed respectively in distilled water $(100 \mathrm{~mL})$ at room temperature for $24 \mathrm{~h}$. Subsequently, the obtained soaked seeds were evenly scattered on a tray covered with a nursery paper $(34 \mathrm{~cm} \times 25 \mathrm{~cm} \times 4.5 \mathrm{~cm}$ ) (for wheat and rapeseed) or in a beaker with a nursery paper (for soybean), and the diluted fertilizer (fertilizer and water with a ratio of $10: 1, \mathrm{v} / \mathrm{v}$ ) were added. The diluted fertilizer solution should be changed every $24 \mathrm{~h}$ for wheat and rapeseed or $12 \mathrm{~h}$ for soybeans. During the crops seeding process, the fertilizers were used as fertigation. After the seedlings had grown for a period of time, the various growth indicators of the seedlings were measured.

The planting time of each crop was based on the local (Sichuan, China) crop planting rule. Specifically, wheat was sown in early October, soybean was sown in midJune, and rapeseed was sown at the end of September.

\subsection{Growth determination of seedlings}

The growth performances of three seedlings were well assessed by the analyzation of growth indexes including growth morphology (e.g. germination rate, plant height and leaf fresh weight), heavy metal content, N, P and $\mathrm{K}$ contents, chlorophyll content and soluble sugar content.

\subsubsection{Germination rate}

The germination rate of seedlings was calculated by counting the number of seeds germination when the wheat, soybean, and rapeseed seeds were cultivated for 5,3 , and 20 days respectively.

\subsubsection{Plant height}

After the cultivation of the wheat, soybean, and rapeseed seeds for 20,10 , and 20 days, respectively, 5 seedlings were randomly selected from each category and then the height from roots (tray) to the highest point of plant was measured using a ruler. Finally, the average value was recorded as the plant height of seedling.

\subsubsection{Leaf fresh weight}

When the wheat, soybean, and rapeseed seeds were cultivated for 20,10 , and 20 days, respectively, 5 seedlings were randomly selected, and the water and the dirt on the roots and leaves of the seedlings were removed. After that, the weight of the clean plant was weighed. Finally, the average value was recorded as the fresh weight of seedling.

\subsubsection{Heavy metal content}

The measurement of the heavy metal content in the seedings was same with that determination of heavy metal content in the AAWSF ("Analysis of collagen hydrolysate" section).

\subsubsection{Nitrogen (N), phosphorus (P) and potassium (K) content}

Before the determination test of N, P, and $\mathrm{K}$ contents, the seedling leaves should be dried using the freezedrying method, and the treatment of the dried seedling leaves was conducted using the $\mathrm{H}_{2} \mathrm{SO}_{4}-\mathrm{H}_{2} \mathrm{O}_{2}$ digestion method [33]. After the digestion, a clear digestion solution was obtained. For the determination of total $\mathrm{N}$ content [34], the digestion solution $(1 \mathrm{~mL})$ and 20 drops of EDTA-methyl red solution were added into a volumetric flask $(50 \mathrm{~mL})$. The $\mathrm{pH}$ of the mixture was adjusted to a value of 6 with $\mathrm{NaOH}$ solution $(0.3 \mathrm{~mol} / \mathrm{L})$. After that, phenol solution $(5 \mathrm{~mL})$ and sodium hypochlorite solution $(5 \mathrm{~mL})$ were sequentially added and the mixture was mixed well, diluted to $50 \mathrm{~mL}$ with distilled water, placed for $1 \mathrm{~h}$ and the absorbance was measured at $625 \mathrm{~nm}$. For the determination of total P content [34], the digestion solution $(10 \mathrm{~mL}), 2$,4-dinitrophenol solution (2 drops) and distilled water $(10 \mathrm{~mL})$ were added into a volumetric flask $(50 \mathrm{~mL})$. The color of mixture was regulated to light yellow using $\mathrm{NaOH}(6 \mathrm{moL} / \mathrm{L})$. After that, the vanadium molybdenum yellow color reagent $(10 \mathrm{~mL})$ was added and the mixture was diluted to $50 \mathrm{~mL}$ with distilled water. The obtained mixture was colored for $15 \mathrm{~min}$ (the temperature was more than $15{ }^{\circ} \mathrm{C}$ ) and the absorbance value of the mixture was measured at $440 \mathrm{~nm}$. The total $\mathrm{K}$ content was determined using the atomic absorption spectrometry.

\subsubsection{Chlorophyll content}

The chlorophyll content in the seedlings was determined by the acetone method [35]. Briefly, the leaves of each species of fresh hydroponic plants were wiped clean and cut. The cut leaves $\left(0.2 \mathrm{~g}, \mathrm{~m}_{0}\right)$, a small amount of quartz sand, calcium carbonate (used to neutralize acidity and prevent the decomposition of chlorophyll from chlorophyll esterase) and a desired amount of $80 \%$ acetone were mixed and grinded until the leaf tissue became white. The ground residue was filtered and washed with $80 \%$ acetone until the filter paper and residue changed to colorless. After that, the green filtrate was collected and diluted to $25 \mathrm{~mL}$ with $80 \%$ acetone using brown volumetric flask that should be covered with tin foil before use. The absorbance values, A663 and A645, of the diluted 
filtrate were measured at $663 \mathrm{~nm}$ (the maximum ultraviolet absorption wavelength of chlorophyll a) and $645 \mathrm{~nm}$ (the maximum ultraviolet absorption wavelength of chlorophyll b), respectively. The chlorophyll content in seedlings was calculated as follows (Arnon formula):

$$
\begin{aligned}
& \mathrm{C}_{\mathrm{a}}(\mathrm{mg} / \mathrm{L})=12.72 \times \mathrm{A} 663-2.59 \times \mathrm{A} 645 \\
& \mathrm{C}_{\mathrm{b}}(\mathrm{mg} / \mathrm{L})=22.88 \times \mathrm{A} 645-4.67 \times \mathrm{A} 663 \\
& \mathrm{C}_{\mathrm{T}}(\mathrm{mg} / \mathrm{L})=\mathrm{C}_{\mathrm{a}}+\mathrm{C}_{\mathrm{b}}=20.29 \times \mathrm{A} 645+8.05 \times \mathrm{A} 663 \\
& \mathrm{M}_{\mathrm{a}}(\mathrm{mg} / \mathrm{g})=\left(\mathrm{C}_{\mathrm{a}} \times \mathrm{V} \times \mathrm{n}\right) /\left(\mathrm{m}_{0} \times 1000\right) \\
& \mathrm{M}_{\mathrm{b}}(\mathrm{mg} / \mathrm{g})=\left(\mathrm{C}_{\mathrm{b}} \times \mathrm{V} \times \mathrm{n}\right) /\left(\mathrm{m}_{0} \times 1000\right) \\
& \mathrm{M}_{\mathrm{T}}(\mathrm{mg} / \mathrm{g})=\mathrm{M}_{\mathrm{a}}+\mathrm{M}_{\mathrm{b}}=\left(\mathrm{C}_{\mathrm{T}} \times \mathrm{V} \times \mathrm{n}\right) /\left(\mathrm{m}_{0} \times 1000\right)
\end{aligned}
$$

where $C_{a}, C_{b}$ and $C_{T}$ are the concentrations $(\mathrm{mg} / \mathrm{L})$ of chlorophyll a, chlorophyll b and total chlorophyll, respectively; $M_{a}, M_{b}$ and $M_{T}$ are the weight $(\mathrm{mg} / \mathrm{g}$ ) of chlorophyll a, chlorophyll $\mathrm{b}$ and total chlorophyll, respectively; $\mathrm{m}_{0}$ is the weight of leaves $(\mathrm{g}) ; \mathrm{V}$ is the volume of the extract $(\mathrm{mL})$ and $\mathrm{n}$ is the dilution factor.

\subsubsection{Soluble sugar content}

The content of soluble sugar in seedlings was determined by anthrone colorimetry [35]. The principle is that soluble sugars are dehydrated using concentrated $\mathrm{H}_{2} \mathrm{SO}_{4}$ to yield aldehydes or hydroxymethyl furfurals that can react with anthrone to form blue-green furfural derivatives (Additional file 1: Fig. S10). The obtained blue-green furfural derivatives were achieved colorimetric and quantitative determination at the wavelength of $630 \mathrm{~nm}$. Before the determination of soluble sugar content in the seedlings, the ethyl anthrone reagent and the standard curve of soluble sugar should be prepared and drawn, respectively, in advance. The preparation of ethyl anthrone reagent was as follows. Anthrone (1.0 g) was well dissolved in a brown volumetric flask containing ethyl acetate $(50 \mathrm{~mL})$. The volumetric flask should be covered with tin foil and stored in the dark. The standard curve of soluble sugar content was operated as follow process. Dry sucrose $(1.0 \mathrm{~g})$ was dissolved in a small amount of water. The concentrated $\mathrm{H}_{2} \mathrm{SO}_{4}(0.5 \mathrm{~mL})$ was slowly added and the mixture was diluted to $100 \mathrm{~mL}$ with distilled water. The sucrose solution $(1 \mathrm{~mL})$ was diluted to $100 \mathrm{~mL}$ with distilled water to obtain sucrose mother solution $(100 \mu \mathrm{g} /$ $\mathrm{mL}$ ). A $50 \mu \mathrm{g} / \mathrm{mL}$ solution of soluble sugar was obtained by diluting $1.0 \mathrm{~mL}$ of the sucrose mother solution into $2 \mathrm{~mL}$. Similarly, the concentration of soluble sugar was diluted into 10, 20, 30 and $40 \mu \mathrm{g} / \mathrm{mL}$, respectively, for the drawing of standard curve. The soluble sugar standard solution $(2 \mathrm{~mL})$, ethyl anthrone $(0.5 \mathrm{~mL})$ and concentrated $\mathrm{H}_{2} \mathrm{SO}_{4}(5 \mathrm{~mL})$ were mixed well and heated in boiling water for $1 \mathrm{~min}$. After that, the mixture was cooled to room temperature and the absorbance value was finally measured at $630 \mathrm{~nm}$. The determination of soluble sugar content in the seedlings was carried out as follows. The leaves of fresh hydroponic plants were wiped clean and cut into many small pieces. These leaf pieces $\left(0.2 \mathrm{~g}, \mathrm{~m}_{0}\right)$ were placed in a test tube containing distilled water $(10 \mathrm{~mL})$ and the test tube was sealed with preservative film and placed in boiling water for $30 \mathrm{~min}$. The heating procedure was repeated for two times to collect all the extracting solution. The extracted solution $(0.5 \mathrm{~mL})$ was added into a test tube containing distilled water $(1.5 \mathrm{~mL})$. And the subsequent steps were the same as the determination of the soluble sugar standard curve. The absorbance of the sample was measured. According to the standard curve of sugar content (Additional file 1: Fig. S11), the content of soluble sugar in seedlings was calculated as follows:

$$
\text { soluble sugar content }(\%)=\frac{\mathrm{m} \cdot \mathrm{V}_{\mathrm{T}}}{\mathrm{m}_{0} \times 0.5 \times 10^{6}} \times 100 \%
$$

where $\mathrm{m}_{0}$ is the weight of leaf pieces $(\mathrm{g}) ; \mathrm{m}$ is the sugar content calculated by standard curve $(\mu \mathrm{g})$ and $\mathrm{V}_{\mathrm{T}}$ is the volume of all the extracting solution $(\mathrm{mL})$.

Notably, the N, P, K, heavy metal, chlorophyll and soluble sugar contents in wheat, soybean and rapeseed plants were determined on the 20th, 10th and 20th day, respectively.

\subsubsection{Statistical analysis}

All the experimental data were expressed as means \pm standard deviations (SD) and the error bar in the figures represents the SD. One-way analysis of variance (ANOVA) was applied to determine the statistical significance, and the significance can be accepted at * $\mathrm{p}<0.05$.

\section{Results and discussion}

\subsection{Preparation of collagen hydrolysate}

The three collagen hydrolysates, including $\mathrm{ACH}, \mathrm{ECH}$ and $\mathrm{AECH}$, were successfully prepared from CS by alkaline, enzymatic and alkaline-enzymatic hydrolysis dechroming methods, respectively. In all the collagen hydrolysates, the protein content was estimated by calculating the hydroxyproline (Hyp) content based on the standard curve of Hyp (Additional file 1: Fig. S1) because the Hyp is special and has relatively high content in collagen hydrolysate [36]. Taking the Hyp content as the testing index, the hydrolysis process parameters (e.g. reaction time, temperature, dosage) 
Table 1 The $\mathrm{pH}$ value, protein and ash contents of $\mathrm{ACH}, \mathrm{ECH}$ and $\mathrm{AECH}$

\begin{tabular}{llcr}
\hline Index & ACH & ECH & AECH \\
\hline pH & $11.7 \pm 0.42$ & $6.7 \pm 0.28$ & $7.2 \pm 0.30$ \\
Protein content ${ }^{\mathrm{a}} \%$ & $71.8 \pm 3.21$ & $76.5 \pm 3.05$ & $81.7 \pm 3.89$ \\
Ash content $/ \%$ & $13.67 \pm 0.58$ & $10.25 \pm 0.49$ & $8.52 \pm 0.38$ \\
\hline a Dry base & & &
\end{tabular}

Table 2 The content of heavy metal in $\mathrm{ACH}, \mathrm{ECH}$ and $\mathrm{AECH}$

\begin{tabular}{llll}
\hline Heavy metal element & ACH & ECH & AECH \\
\hline Total $\mathrm{Cr}^{\mathrm{a}}(\mathrm{mg} / \mathrm{kg})$ & $783 \pm 32$ & $356 \pm 12$ & $482 \pm 20$ \\
$\mathrm{Hg}^{\mathrm{a}}(\mathrm{mg} / \mathrm{kg})$ & - & - & - \\
$\mathrm{As}^{\mathrm{a}}(\mathrm{mg} / \mathrm{kg})$ & - & - & - \\
$\mathrm{Cd}^{\mathrm{a}}(\mathrm{mg} / \mathrm{kg})$ & - & - & - \\
$\mathrm{Pb}^{\mathrm{a}}(\mathrm{mg} / \mathrm{kg})$ & - & - & - \\
\hline
\end{tabular}

"a" means dry base;" - " means not be detected

\subsection{Analysis of collagen hydrolysates}

The $\mathrm{pH}$ value, protein, ash and heavy metal contents, MW and amino acid composition of the obtained collagen hydrolysates were analyzed. Table 1 showed the $\mathrm{pH}$ value, protein and ash contents of three hydrolysates. The $\mathrm{pH}$ of $\mathrm{ACH}, \mathrm{ECH}$ and $\mathrm{AECH}$ was $11.7,6.7$ and 7.2, respectively. In addition, the results revealed that all the hydrolysates were mainly composed of protein and contained a small amount of ash and moisture. It is worth noting that the protein content of $\mathrm{ACH}, \mathrm{ECH}$ and $\mathrm{AECH}$ was $71.8,76.5$ and $81.7 \%$, respectively, demonstrating that CS had a good protein recycle value and the alkalienzyme synergistic hydrolysis was the best method for the production of collagen hydrolysate from CS.

The heavy metal contents in collagen hydrolysates were investigated by the inductively coupled plasma emission spectroscopy (ICP). As shown in Table 2, the chromium contents in $\mathrm{ACH}, \mathrm{ECH}$ and $\mathrm{AECH}$ were 783, 356 and $482 \mathrm{mg} / \mathrm{kg}$, respectively. Meanwhile, the other heavy metals, such as mercury ( $\mathrm{Hg})$, arsenic (As), cadmium
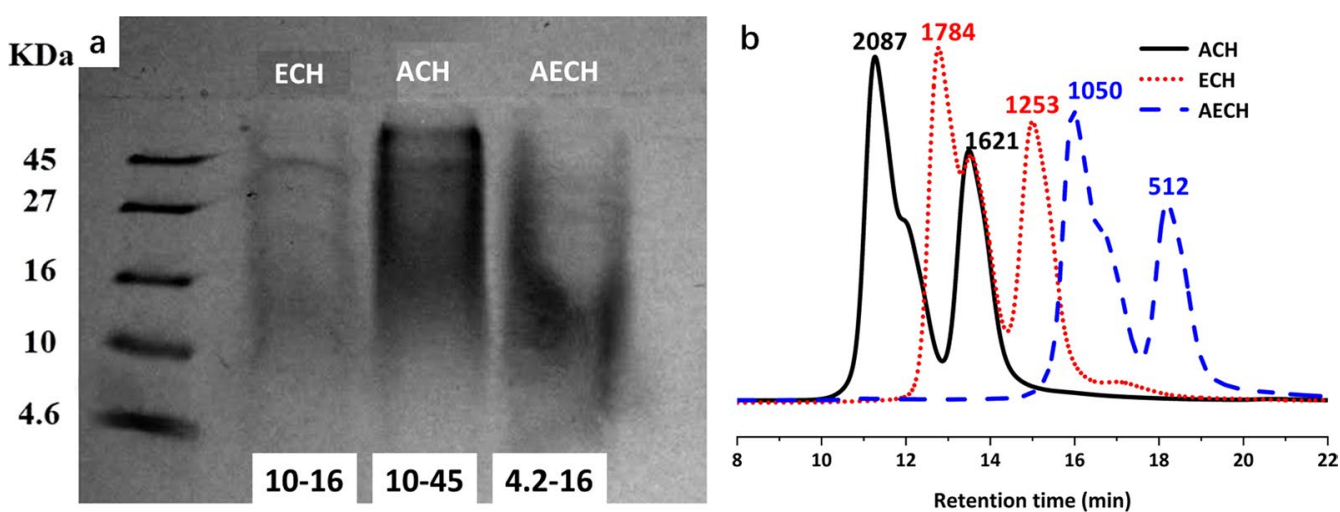

Fig. 1 MWs of the collagen hydrolysates. a SDS-PAEG pictures. b GPC curves

for the preparation of $\mathrm{ACH}, \mathrm{ECH}$ and $\mathrm{AECH}$ were optimized through the single factor and orthogonal experiments (Additional file 1: Tables S1-S4 and Additional file 1: Figs. S2-S3). Concretely, for the $\mathrm{ACH}$, the optimal dosage of $\mathrm{NaOH}$, hydrolysis temperature and hydrolysis time were $6 \%, 55^{\circ} \mathrm{C}$ and $9 \mathrm{~h}$, respectively, and the obtained Hyp content was $48.12 \mathrm{mg} / \mathrm{g}$. For the ECH, the optimal usage of 1398 neutral protease, hydrolysis temperature and hydrolysis time were $6.25 \%, 55^{\circ} \mathrm{C}$ and $7 \mathrm{~h}$, respectively, and the Hyp content reached to $51.25 \mathrm{mg} / \mathrm{g}$. For the $\mathrm{AECH}$, it was obtained by using the optimal alkaline hydrolysis process followed by the optimum enzymatic hydrolysis treatment, and the resultant Hyp content was up to $54.74 \mathrm{mg} / \mathrm{g}$. The concrete analyses for the optimal experiments can be seen in the SI.
(Cd) and plumbum $(\mathrm{Pb})$ were not detected in all the hydrolysates.

The MW of hydrolysis product was characterized by the sodium dodecyl sulphate-polyacrylamide gel electrophoresis (SDS-PAGE) and gel permeation chromatography (GPC). As shown in Fig. 1a, the MW distribution of $\mathrm{ACH}$ was wide and continuous, mainly between 10-45 $\mathrm{KDa}$ and above $45 \mathrm{KDa}$. The $\mathrm{MW}$ of $\mathrm{ECH}$ was dominantly distributed between $10-16 \mathrm{KDa}$, and a small amount was distributed between 27-45 KDa. The MW of the AECH was mainly distributed between 4.6-16 $\mathrm{KDa}$. Notably, the MW of AECH was the smallest. This is mainly because the 1398 protease can further hydrolyze the gelatin or polypeptide, which was obtained by the hydrolysis process of $\mathrm{NaOH}$, to generate small molecule polypeptides or amino acids [37, 38]. GPC also illustrated 
Table 3 Amino acid composition of $\mathrm{ACH}, \mathrm{ECH}$ and $\mathrm{AECH}$

\begin{tabular}{|c|c|c|c|}
\hline Samples & $\begin{array}{l}\mathrm{ACH} \\
(\mathrm{mg} / \mathrm{g})\end{array}$ & $\begin{array}{l}\mathrm{ECH} \\
(\mathrm{mg} / \mathrm{g})\end{array}$ & $\begin{array}{l}\text { AECH } \\
(\mathrm{mg} / \mathrm{g})\end{array}$ \\
\hline Aspartic acid & $5.983 \pm 0.231$ & $2.409 \pm 0.231$ & $7.469 \pm 0.401$ \\
\hline Glutamic acid & $12.929 \pm 0.520$ & $5.440 \pm 0.326$ & $9.127 \pm 0.445$ \\
\hline Asparaginate & 0.000 & 0.000 & 0.000 \\
\hline Serine & $5.048 \pm 0.189$ & $2.042 \pm 0.319$ & $3.690 \pm 0.324$ \\
\hline Glutamine & 0.000 & $0.545 \pm 0.014$ & $0.494 \pm 0.011$ \\
\hline Histidine & 0.000 & 0.000 & 0.000 \\
\hline Glycine & $23.060 \pm 0.757$ & $14.513 \pm 0.563$ & $20.870 \pm 0.856$ \\
\hline Threonin & $3.791 \pm 0.199$ & $2.031 \pm 0.253$ & $2.661 \pm 0.145$ \\
\hline Citrulline & 0.000 & 0.000 & 0.000 \\
\hline Arginine & $4.515 \pm 0.320$ & $2.867 \pm 0.324$ & $3.990 \pm 0.248$ \\
\hline Alanine & $7.848 \pm 0.426$ & $7.589 \pm 0.459$ & $6.409 \pm 0.398$ \\
\hline Tyrosine & $2.227 \pm 0.098$ & $3.226 \pm 0.226$ & $1.535 \pm 0.142$ \\
\hline Cysteine & $7.178 \pm 0.520$ & $3.362 \pm 0.296$ & $4.749 \pm 0.352$ \\
\hline Valine & $3.221 \pm 0.241$ & $7.005 \pm 0.322$ & $5.216 \pm 0.357$ \\
\hline Methionine & $0.650 \pm 0.023$ & 0.000 & $0.751 \pm 0.029$ \\
\hline Norvaline & $2.232 \pm 0.210$ & $3.890 \pm 0.389$ & $3.302 \pm 0.299$ \\
\hline Tryptophan & $1.527 \pm 0.142$ & 0.000 & $2.294 \pm 0.239$ \\
\hline Phenylalanine & $3.458 \pm 0.359$ & $3.070 \pm 0.298$ & $2.779 \pm 0.201$ \\
\hline Isoleucine & $2.200 \pm 0.169$ & $3.726 \pm 0.329$ & $3.117 \pm 0.289$ \\
\hline Leucine & $3.856 \pm 0.365$ & $4.214 \pm 0.315$ & $3.763 \pm 0.346$ \\
\hline Lysine & $3.874 \pm 0.334$ & $2.236 \pm 0.186$ & $3.173 \pm 0.299$ \\
\hline Hydroxyproline & $23.646 \pm 0.887$ & $4.261 \pm 0.426$ & $14.241 \pm 0.464$ \\
\hline Sarcosine & $0.874 \pm 0.053$ & $1.211 \pm 0.99$ & $0.137 \pm 0.009$ \\
\hline Proline & $14.378 \pm 0.542$ & $5.486 \pm 0.347$ & $11.813 \pm 0.461$ \\
\hline
\end{tabular}

the MW distribution of each hydrolysate versus polyethylene oxide (PEO) standard (Fig. 1b). It can be found that the MW of $\mathrm{ACH}$ was smaller than that of $\mathrm{ECH}$, and the MW of AECH was the smallest. However, the determined MW values by GPC $\left(M_{n}, D a\right)$ were smaller than that of SDS-PAEG. This is because the large structural difference between the PEO and collagen hydrolysates. Notably, two obvious peaks were found in each curve, where the first (high) and second (low) pinnacles may represent the polypeptide and small amino acids, respectively, all of which were yielded in the hydrolysis process.

The amino acid composition of three collagen hydrolysates was also analyzed and their results were shown in Table 3. In general, 20 types of amino acids, including aspartic acid, glutamic acid, serine, glycine, threonine, arginine, alanine, tyrosine, cysteine, valine, methionine, norvaline, tryptophan, phenylalanine, isoleucine, leucine, lysine, hydroxyproline, sarcosine and proline, were found in $\mathrm{ACH}$. The amino acid composition of $\mathrm{ECH}$ was similar with that of $\mathrm{ACH}$. The difference between them was that glutamine was discovered in $\mathrm{ECH}$, whilst the methionine and tryptophan were not found in $\mathrm{ECH}$. Interestingly, all the amino acids that appeared in the $\mathrm{ACH}$ and
$\mathrm{ECH}$ can be found in the AECH. Also, according to the content of each amino acid in the three collagen hydrolysates, it can be found that the three hydrolysates mainly contained glycine, hydroxyproline, proline and alanine. And traces of tyrosine indicated that there were telopeptide residues in the all hydrolysates [39]. Moreover, most essential amino acids, such as lysine, valine, phenylalanine, leucine, isoleucine, threonine and methionine, were observed in the composition of hydrolysates. Thus, this is an important point for selecting collagen hydrolysates from CS to prepare active formulations used as plant growth ingredients and animal feed additives. [40].

\subsection{Mortality, hatchability and medial lethal concentration of zebrafish embryos}

According to the OECD manual [31], the zebrafish embryos can be used as animal model to evaluate the biosafety of the three collagen hydrolysates extracted from CS. The effects of embryos nutrient solution and different concentrations of hydrolysates solutions on zebrafish embryos development were observed and recorded until $96 \mathrm{hpf}$.

\subsubsection{Effect of ACH on the mortality and hatchability of zebrafish embryos}

The effect of $\mathrm{ACH}$ on the mortality and hatchability of zebrafish embryos was evaluated by the concentration scaling method. Firstly, the zebrafish embryos were treated with $\mathrm{ACH}$ at the concentrations of $0.01,0.1,1.0$, 10 and $20 \mathrm{mg} / \mathrm{mL}$, respectively. The mortality and hatchability of zebrafish embryos were calculated at 24, 48, 72 and 96 hpf, respectively. As shown in Fig. 2a, b, compared with the blank group, at $48 \mathrm{hpf}$, all the zebrafish embryos died and no hatched embryos appeared when they were incubated with a high concentration solution of $\mathrm{ACH}$ $(\geq 1.0 \mathrm{mg} / \mathrm{mL})$. At $96 \mathrm{hpf}$, the mortality and hatchability of embryos at low concentration $(0.01$ and $0.1 \mathrm{mg} / \mathrm{mL})$ were $10 \%$ and $90 \%$, respectively. Therefore, the critical concentrations of $\mathrm{ACH}$ that could affect mortality and hatchability of zebrafish embryos are 0.1 and $1.0 \mathrm{mg} / \mathrm{mL}$. That is, zebrafish embryos cultivated with $\mathrm{ACH}$ with a concentration lower than $0.1 \mathrm{mg} / \mathrm{mL}$ can be developed normally, but all zebrafish embryos died when they were cultivated above $1.0 \mathrm{mg} / \mathrm{mL}$. Additionally, based on the above critical concentrations $(0.1$ and $1.0 \mathrm{mg} / \mathrm{mL})$, we further investigated the effects of $\mathrm{ACH}$ with concentrations of $0.1,0.3,0.5,0.8$ and $1.0 \mathrm{mg} / \mathrm{mL}$, respectively, on the mortality and hatchability of zebrafish embryos at same time intervals. As depicted in Fig. 2c, d, compared with the blank group, the mortality of zebrafish embryos cultured with the concentration of $0.1-0.5 \mathrm{mg} / \mathrm{mL}$ was maintained within $3 \%$ with the extension of exposure time. However, when the zebrafish embryos were 

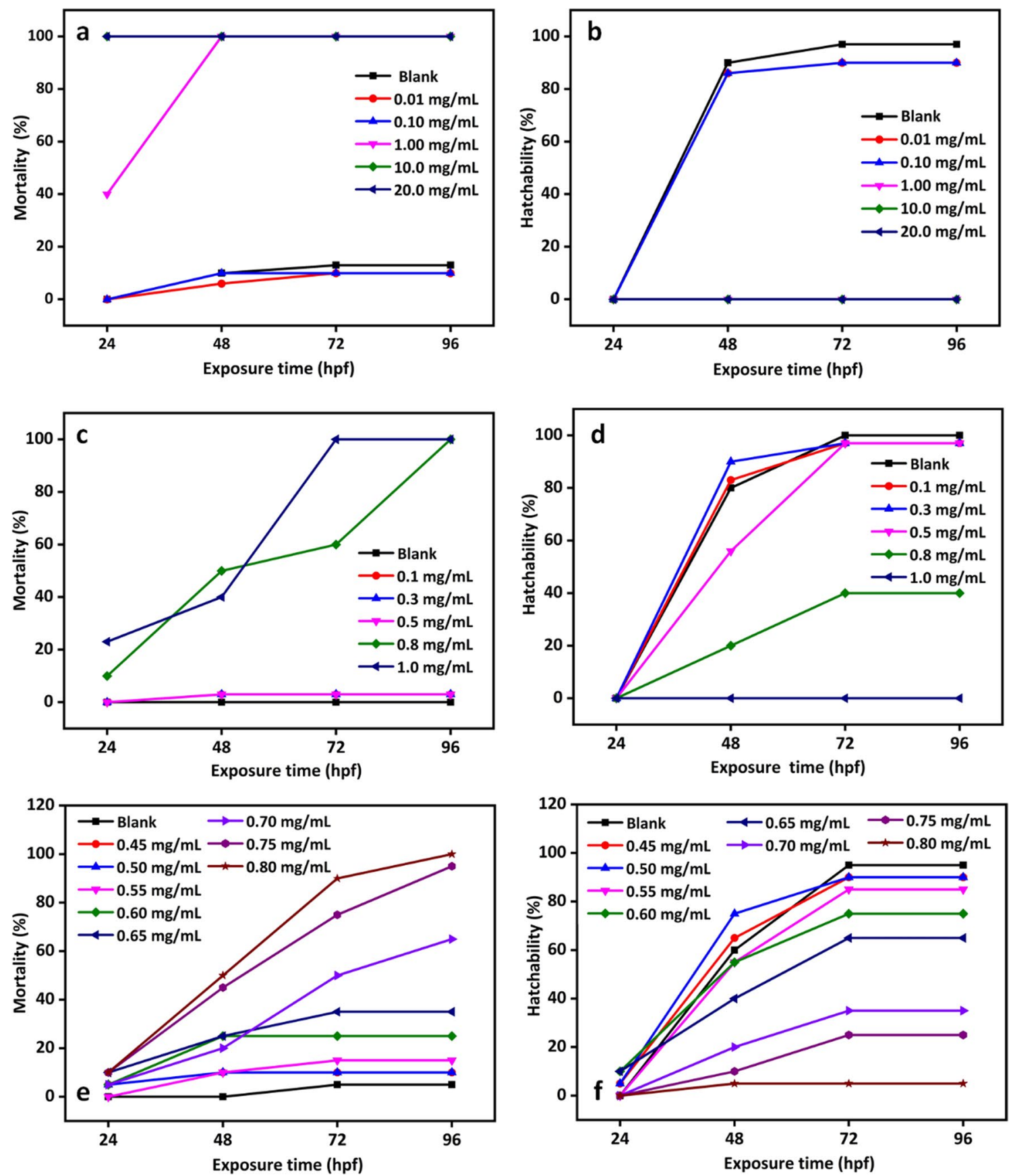

Fig. $\mathbf{2}$ a, $\mathbf{b}$ The mortality and hatchability of zebrafish embryos within the range of ACH concentration of $0.01-20 \mathrm{mg} / \mathrm{mL}$. $\mathbf{c}, \mathbf{d}$ The $\mathrm{mortality}$ and hatchability of zebrafish embryos within the range of ACH concentration of $0.1-1.0 \mathrm{mg} / \mathrm{mL}$. e, $\mathbf{f}$ The mortality and hatchability of zebrafish embryos within the range of $\mathrm{ACH}$ concentration of $0.45-0.80 \mathrm{mg} / \mathrm{mL}$

cultured in the 0.8 and $1.0 \mathrm{mg} / \mathrm{mL}$ solutions, the mortalities of them increased with the increase of exposure time and even reached $100 \%$ at $96 \mathrm{hpf}$. In terms of hatchability, no hatched embryos appeared when they were farmed in $1.0 \mathrm{mg} / \mathrm{mL}$ solution. Interestingly, the hatchability of embryos cultivated in the concentration range of $0.1-0.8 \mathrm{mg} / \mathrm{mL}$ increased with the extension of exposure time. Especially, the hatchability of embryos farmed in $0.1-0.5 \mathrm{mg} / \mathrm{mL}$ solutions increased most obviously, which can be as high as $97 \%$ at $72 \mathrm{hpf}$; but the hatchability of embryos treated with the $0.8 \mathrm{mg} / \mathrm{mL}$ only reached up to $40 \%$. Based on these results, it can be seen that 
zebrafish embryos cultivated with $\mathrm{ACH}$ at the concentrations lower than $0.5 \mathrm{mg} / \mathrm{mL}$ could develop normally, while the higher concentrations (more than $0.8 \mathrm{mg} / \mathrm{mL}$ ) were lethal to zebrafish embryos. Moreover, in order to further intensively study the accurate effect of concentration of $\mathrm{ACH}$ on the mortality and hatchability of zebrafish embryos, the concentration in the range of $0.45-0.8 \mathrm{mg} /$ $\mathrm{mL}$ was considered and measured. Figure $2 \mathrm{e}, \mathrm{f}$ showed the mortality and hatchability of zebrafish embryos at different exposure time. Generally, these two figures all showed a clear dose-effect relationship. Namely, the mortality was increased with the increase of hydrolysate concentration, while the hatchability was opposite. However, the mortality curves of zebrafish embryos cultured with $0.55 \mathrm{mg} / \mathrm{mL}$ and $0.7 \mathrm{mg} / \mathrm{mL}$ at $24 \mathrm{hpf}$, and $0.55 \mathrm{mg} /$ $\mathrm{mL}$ at $48 \mathrm{hpf}$ displayed a rebound trend. This may be due to the death of very few zebrafish embryos caused by their own problems (individual differences), which can be attributed to the normal death. Significantly, at $24 \mathrm{hpf}$, compared with the blank group, the embryos cultured with the low concentrations of $\mathrm{ACH}$ solutions (0.45$0.65 \mathrm{mg} / \mathrm{mL}$ ) had a higher hatchability, demonstrating that the $\mathrm{ACH}$ with low concentration solutions can promote the hatching process. This is properly because the hydrolyzed proteins in the low concentration solution can provide more nutrients for zebrafish embryos, leading to their higher hatching development [41-43]. However, with the further extension of cultivating time, the hatchability began reduced with the increase of $\mathrm{ACH}$ concentrations, indicating that the higher the concentration, the more obvious the inhibitory effect on the hatching of zebrafish embryo. This is because the $\mathrm{ACH}$ with high concentration may make the yolk sac (hatching site of zebrafish) deformity (e.g. edema) and affect the secretion or activity of hatching enzyme (chorionic enzyme), leading to the abnormal hatching of embryos $[41,44,45]$.

\subsubsection{Effect of ECH on the mortality and hatchability of zebrafish embryos}

Similarly, the same method was used to evaluate the effect of ECH on the mortality and hatchability of zebrafish embryos and their results was shown in Fig. 3. When the embryos were cultured in the second set of designed concentration ranges, it can be found that the embryos can grow normally in the low ECH concentration $(<0.5 \mathrm{mg} / \mathrm{mL})$, while higher concentrations $(0.8 \mathrm{mg} /$ $\mathrm{mL}$ ) had a strong lethal effect on embryos. Furthermore, when the ECH concentration was continuously scaled to $0.45-0.8 \mathrm{mg} / \mathrm{mL}$, a clear dose-effect relationship could be discovered between concentration and mortality/ hatchability (Fig. 3e, f). That is, the mortality of embryos increased with the improvement of cultivating concentration, but the hatchability was the contrary. But the embryos fed with ECH $(0.5 \mathrm{mg} / \mathrm{mL})$ at $48 \mathrm{hpf}$ was not in accordance with the above rule, which can be attributed to the individual differences and the normal death. Meanwhile, at $24 \mathrm{hpf}$, the hatchability of embryos cultured with low concentrations of ECH solution $(0.5-0.65 \mathrm{mg} / \mathrm{mL})$ was slightly higher than that of blank group, indicating that $\mathrm{ECH}$ with the low concentrations can accelerate the embryonic hatching process. However, the development of embryos was opposite when they were treated with high concentrations $(>0.65 \mathrm{mg} / \mathrm{mL})$, which is because the high concentration can cause teratogenicity of yolk sac of zebrafish embryos, resulting in the inhibitory effect on hatching [41].

\subsubsection{Effect of AECH on the mortality and hatchability of zebrafish embryos}

Also, the same method was applied to assess the effect of $\mathrm{AECH}$ on the mortality and hatchability of zebrafish embryos and their results were provided in Fig. 4. After three sets of experiments, it can be concluded that the low concentration of AECH solution $(0.5-0.65 \mathrm{mg} / \mathrm{mL})$ had a significant and positive effect on the hatching of zebrafish embryos. Whereas embryos growth was the contrary when they were cultured in high AECH concentration solution $(\geq 0.7 \mathrm{mg} / \mathrm{mL})$ owing to the malformation of embryos yolk sac, leading to hinder their growth and development [41, 43].

The medial lethal concentration $\left(\mathrm{LC}_{50}\right)$ can be utilized to evaluate the toxicity of three collagen hydrolysates. $\mathrm{LC}_{50}$ can be calculated by the probit regression analysis [41] using the software of Origin 8.6. Here, the $\mathrm{LC}_{50}$ of zebrafish embryos at $24 \mathrm{hpf}$ was not determined because the mortality of them was much less than $50 \%$, and the other $\mathrm{LC}_{50}$ values at 48,72 and $96 \mathrm{hpf}$ were calculated. As shown in Fig. 5 and Additional file 1: Table S6, the $48 \mathrm{~h}-\mathrm{LC}_{50}$ values of $\mathrm{ACH}, \mathrm{ECH}$ and $\mathrm{AECH}$ were calculated to be $0.81,0.65,0.71 \mathrm{mg} / \mathrm{mL}$, respectively; the $72 \mathrm{~h}-\mathrm{LC}_{50}$ values of them were $0.66,0.63$ and $0.66 \mathrm{mg} /$ $\mathrm{mL}$, respectively; the $96 \mathrm{~h}-\mathrm{LC}_{50}$ values of them were 0.67 , 0.62 and $0.67 \mathrm{mg} / \mathrm{mL}$, respectively. According to the Acute Toxicity Rating Scale by Fish and Wildlife Service established by the United States Fish and Wildlife service [41] (Additional file 1: Table S6), the three collagen hydrolysates presented the characteristic of "Practically Nontoxic".

\subsection{Morphological development and deformity of zebrafish embryos}

According to the above effects of $\mathrm{ACH}, \mathrm{ECH}$ and $\mathrm{AECH}$ on the mortality and hatchability of zebrafish embryos, the collagen hydrolysates from CS had almost no influence on zebrafish embryos when their concentrations were less than $0.45 \mathrm{mg} / \mathrm{mL}$, and the death of zebrafish 

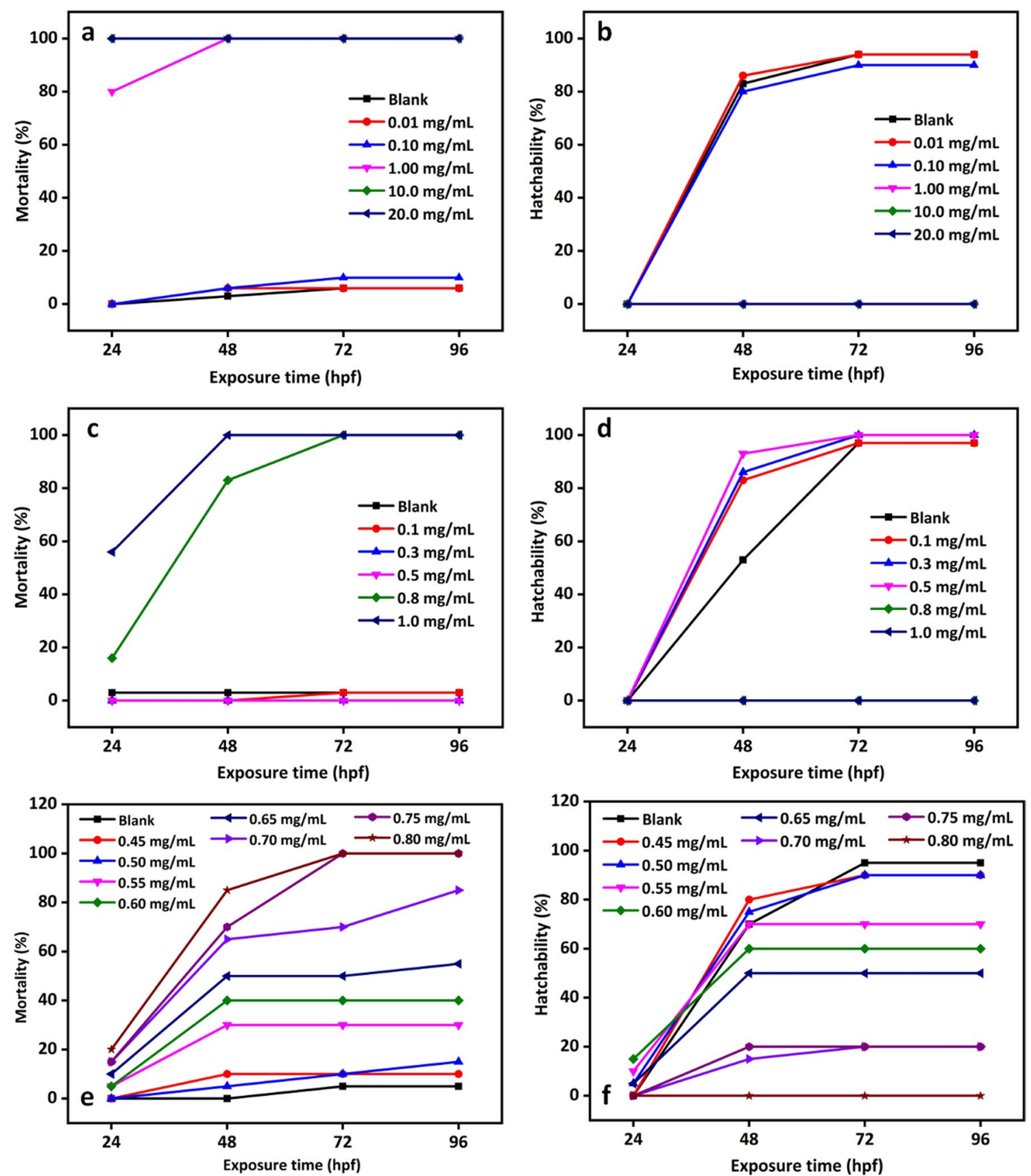

Fig. 3 a, b The mortality and hatchability of zebrafish embryos within the range of ECH concentration of $0.01-20 \mathrm{mg} / \mathrm{mL}$. c, $\mathbf{d}$ The mortality and hatchability of zebrafish embryos within the range of ECH concentration of $0.1-1.0 \mathrm{mg} / \mathrm{mL}$. e, $\mathbf{f}$ The mortality and hatchability of zebrafish embryos within the range of ECH concentration of $0.45-0.80 \mathrm{mg} / \mathrm{mL}$

embryos was very serious when they were cultured in high concentration solutions $(>0.65 \mathrm{mg} / \mathrm{mL})$. Therefore, the growth changes (morphological development) of embryos were recorded when they were raised in the hydrolysate solutions in the concentration range of $0.45-$ $0.65 \mathrm{mg} / \mathrm{mL}$ and the results were shown in Additional file 1: Figs. S4-S6. At $24 \mathrm{hpf}$, all the zebrafish embryos in the blank group developed normally and were not hatched, while a small amount of hatching embryos were observed when they were cultivated with $\mathrm{ACH}(0.65 \mathrm{mg} /$ $\mathrm{mL}), \mathrm{ECH}(0.5,0.6$ and $0.65 \mathrm{mg} / \mathrm{mL})$ and $\mathrm{AECH}(0.5$, $0.55,0.60$ and $0.65 \mathrm{mg} / \mathrm{mL}$ ) (see the red arrow and the 

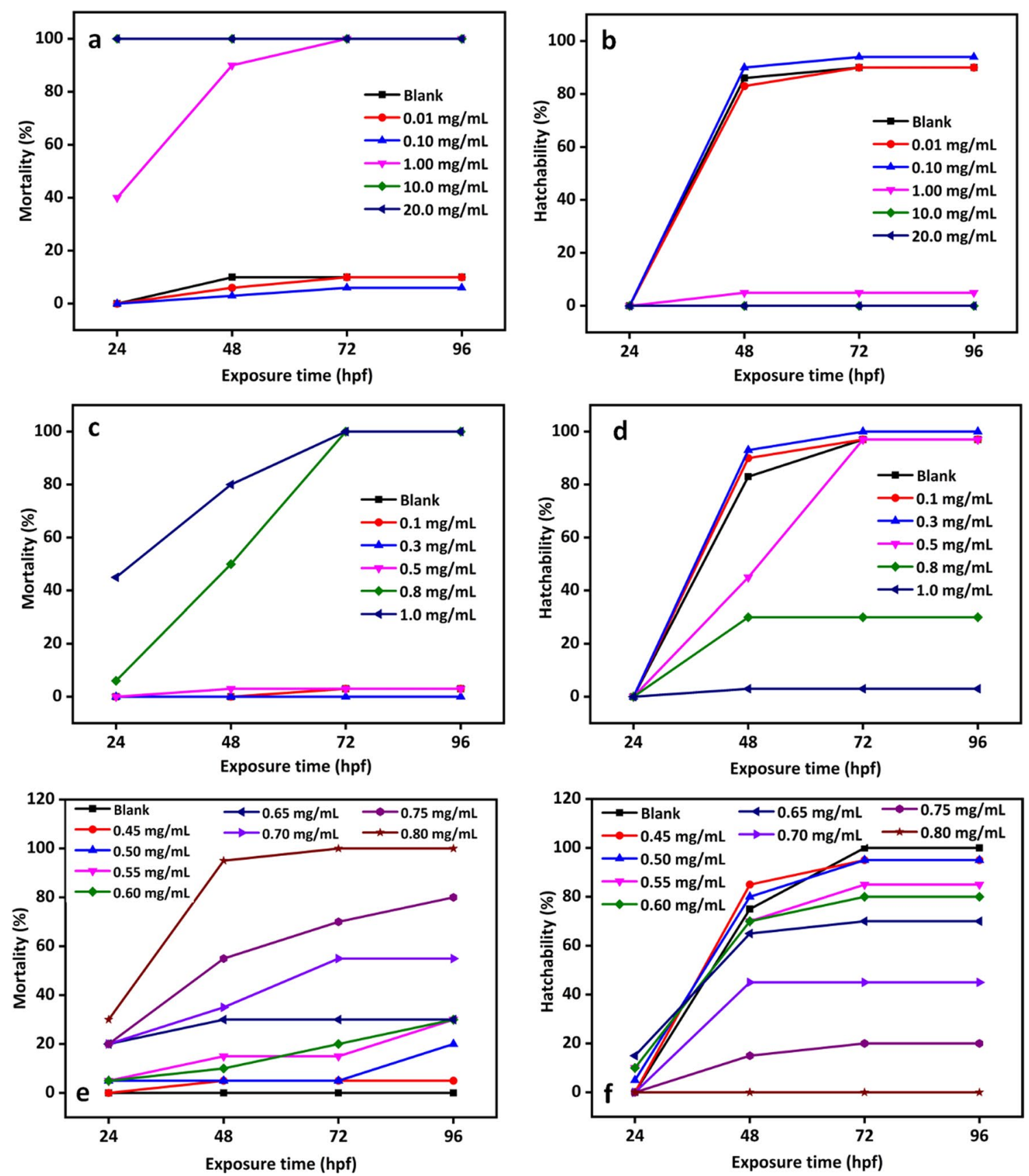

Fig. 4 a, $\mathbf{b}$ The mortality and hatchability of zebrafish embryos within the range of AECH concentration of $0.01-20 \mathrm{mg} / \mathrm{mL}$. c, $\mathbf{d}$ The $\mathrm{mortality}$ and hatchability of zebrafish embryos within the range of $\mathrm{AECH}$ concentration of $0.1-1.0 \mathrm{mg} / \mathrm{mL}$. e, $\mathbf{f}$ The mortality and hatchability of zebrafish embryos within the range of $A E C H$ concentration of $0.45-0.80 \mathrm{mg} / \mathrm{mL}$

enlarged image in Additional file 1: Figs. S4-S6). This is because the promotion effect of protein from the hydrolysates on zebrafish embryos was stronger than the inhibitory of heavy metals and other toxic substances, resulting in an overall development-promoting effect. At $48 \mathrm{hpf}$, all the zebrafish embryos in the experimental groups began to hatch, and the enlarged image was the unhatched embryos in the blank group. At $72 \mathrm{hpf}$, it is interesting that both zebrafish embryos of the blank and the experimental groups hatched into larvae. Thus, the growth and development of zebrafish larvae can be analyzed in this time. Meanwhile, the larvae were in the 

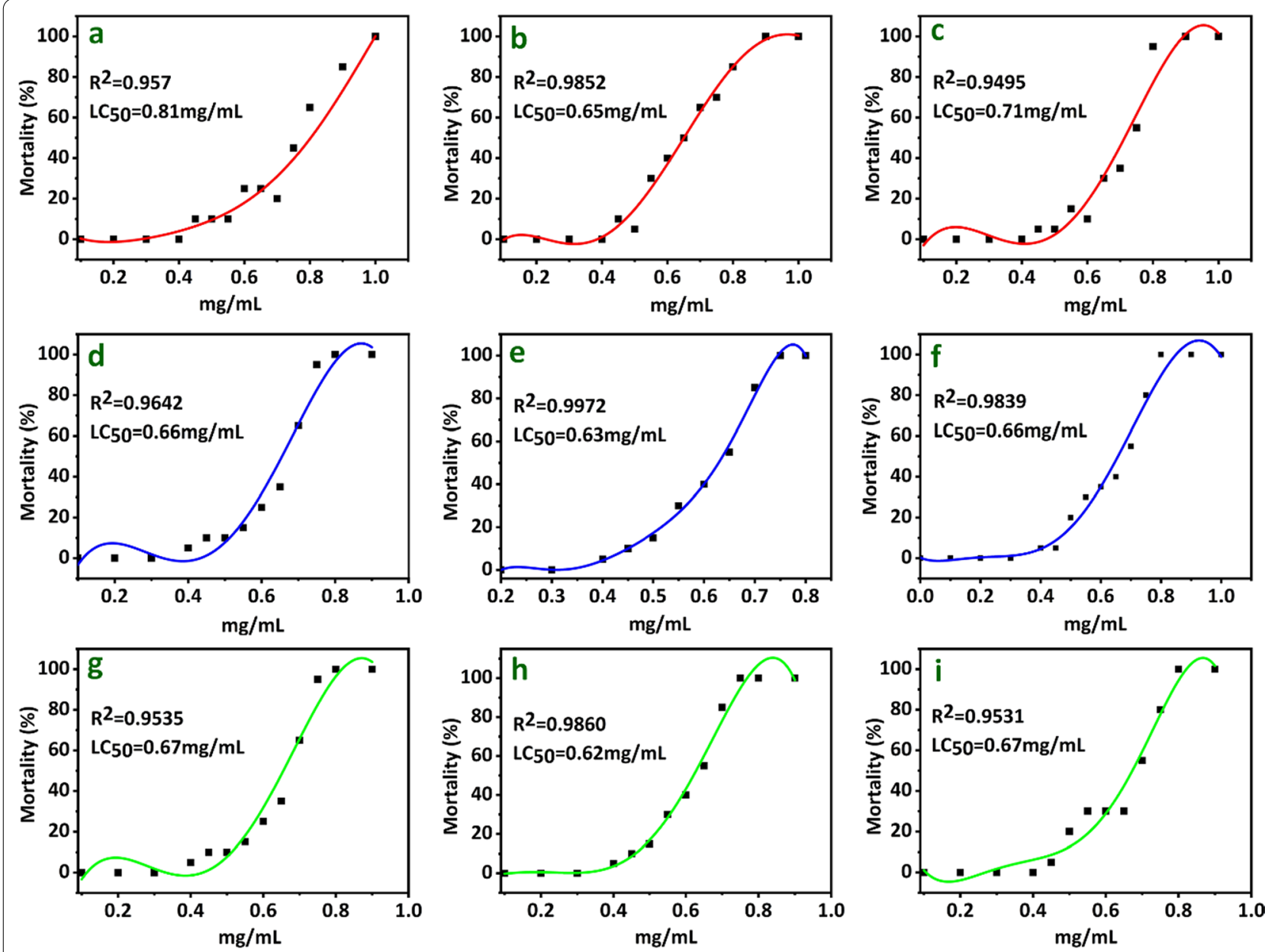

Fig. 5 a-c Mortality-concentration fitted curves of $\mathrm{ACH}(\mathbf{a}), \mathrm{ECH}(\mathbf{b})$ and $\mathrm{AECH}$ (c) at $48 \mathrm{hpf}$. $\mathbf{d}$-f Mortality-concentration fitted curves of ACH (d), $\mathrm{ECH}(\mathbf{e})$ and $\mathrm{AECH}(\mathbf{f})$ at 72 hpf. $\mathbf{g}$-i Mortality-concentration fitted curves of $\mathrm{ACH}(\mathbf{g}), \mathrm{ECH}(\mathbf{h})$ and $\mathrm{AECH}(\mathbf{i})$ at 96 hpf

newly hatched state with low activity (e.g. swimming), which was suitable for the determination of abnormality, body length, pericardial area and $20 \mathrm{~s}$ heartbeat. At $96 \mathrm{hpf}$, the larvae were already very lively, and it was difficult to keep them static under the microscope, which made the measurement of larvae development tough. Additionally, the zebrafish embryos cultured in the blank group and $\mathrm{AECH}$ with the concentration of $0.55 \mathrm{mg} / \mathrm{mL}$ manifested a deformed phenomenon-spinal curvature (see red arrow in Additional file 1: Fig. S6).

Compared with the normal form of the zebrafish embryos (Fig. 6a), deformities mainly manifested pericardial edema, spinal curvature, embryo division and tail knotting (Fig. 6b-f). The deformity rates of zebrafish embryos cultured in different concentrations of different types of hydrolysates were calculated and the corresponding results were shown in Fig. 6g-i. Generally, three different hydrolysates had similar laws for zebrafish embryos malformations. Namely, the teratogenicity rate of zebrafish embryos became more obvious and serious with the increase of hydrolysate concentration. The deformity of zebrafish embryos in all the concentrations of $\mathrm{ACH}$ showed an increase to some extent, and the largest deformity was exhibited in the groups of high concentrations $(0.75$ and $0.80 \mathrm{mg} / \mathrm{mL}, 80 \%, p<0.01)$, while the groups of higher concentrations $(0.60-0.70 \mathrm{mg} /$ $\mathrm{mL}$ ) had a slightly higher deformity than the blank and the groups of low concentrations $(0.45-0.55 \mathrm{mg} / \mathrm{mL}$, $p<0.05$, Fig. $6 \mathrm{~g}$ ), indicating that high concentrations of hydrolysate had a greater impact on the teratogenicity of zebrafish embryos. The deformity of zebrafish embryos in all the concentrations of $\mathrm{ECH}$ and $\mathrm{AECH}$ also displayed an improvement to some extent, and the largest deformity was exhibited in the groups of high concentrations $(0.80 \mathrm{mg} / \mathrm{mL}, p<0.01)$, while the groups of higher concentrations $(0.70-0.75 \mathrm{mg} / \mathrm{mL})$ had a slightly higher deformity than the blank and the groups of low concentrations $(0.45-0.65 \mathrm{mg} / \mathrm{mL}, p<0.05$, Fig. 6h, i). These 

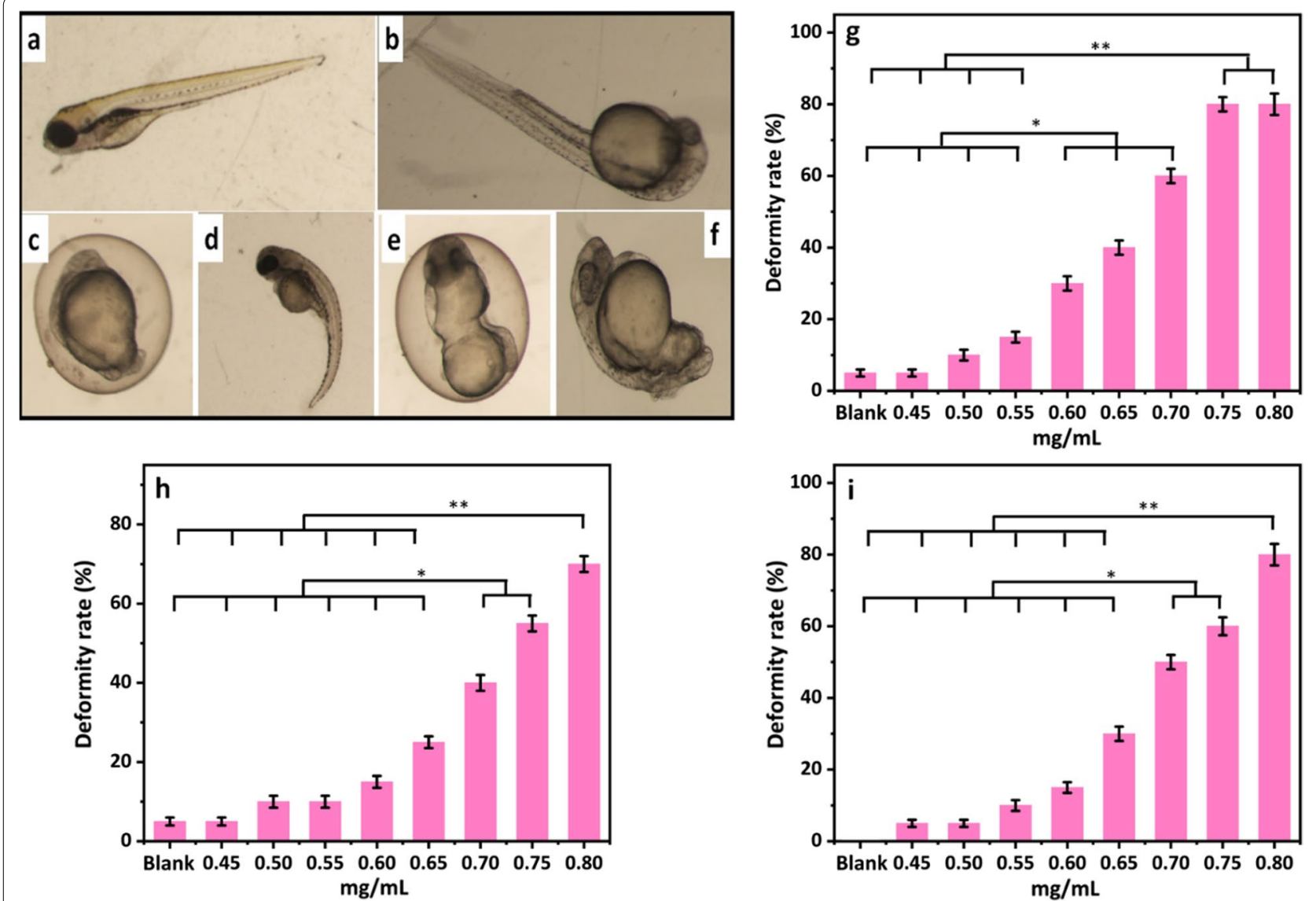

Fig. 6 a The picture of normal morphology of zebrafish embryo. b-f Representative images of deformity of zebrafish embryos (b, c: pericardial edema; d: spinal curvature; e: embryo division; f: tail knotting). Deformity rates of zebrafish embryos cultured in different concentration of ACH (g), $\mathrm{ECH}(\mathbf{h})$ and $\mathrm{AECH}(\mathbf{i})$ at $72 \mathrm{hpf}$ (the experiment was repeated three times, $\mathrm{n}=3$ ). ${ }^{*} P<0.05$, ${ }^{* *} P<0.01$

results also demonstrated that high concentration of hydrolysate had an important impact on the teratogenicity of zebrafish embryos. The cause of zebrafish embryo malformation may be due to the presence of $\mathrm{Cr}$ in hydrolysates. It can increase the level of reactive oxygen species and the content of malondialdehyde in zebrafish embryos and their larvae, resulting in the cells apoptosis of heads, spine and tail of embryos or larvae, and deformities of embryos or larvae [46].

\subsection{Body length and cardiomyogenesis of zebrafish embryos}

The body length, as the most intuitive form of zebrafish growth and development, is an important parameter for evaluating the potential toxicity of nocuous substances to fish [41-43]. The body length of zebrafish embryos cultured in different types of hydrolysates at $72 \mathrm{hpf}$ was recorded. As shown in Fig. 7a, compared with the blank group, the $\mathrm{ACH}$ of low concentration groups $(\leq 0.60 \mathrm{mg} /$ $\mathrm{mL}$ ) showed different body lengths for zebrafish larvae, with values of $3382 \pm 100,3390 \pm 90,3410 \pm 80$, $3438 \pm 90$, and $3534 \pm 80 \mu \mathrm{m}$ for the blank, 0.45, 0.50, 0.55 , and $0.60 \mathrm{mg} / \mathrm{mL}$ groups, respectively. And there was no difference in body length of zebrafish larvae between the blank and low concentration groups $(\leq 0.60 \mathrm{mg} / \mathrm{mL}$, $p>0.05)$. However, the zebrafish larvae cultured in $\mathrm{ACH}$ of high concentration groups $(0.65-0.70 \mathrm{mg} / \mathrm{mL})$ displayed lower body length compared with the blank and low concentration groups $(p<0.05)$, indicating that low concentration groups of $\mathrm{ACH}$ had promotion effect for the body length of zebrafish larvae. For the $\mathrm{ECH}$ and $\mathrm{AECH}$, when high concentrations $(0.65-0.70 \mathrm{mg} / \mathrm{mL})$ were applied to zebrafish larvae, their body length displayed a reduction to some extent compared with the blank group and low concentration groups $(\leq 0.60 \mathrm{mg} /$ $\mathrm{mL}, p<0.05)$, indicating that the high concentrations had an inhibitory effect on zebrafish body length growth. In all, when the concentrations of three collagen hydrolysates exceeded $0.60 \mathrm{mg} / \mathrm{mL}$, the body length growth of zebrafish embryos was inhibited compared with blank 




Fig. 7 Effects of three collagen hydrolysates with different concentration on the body length (a), pericardial area (b) and 20 s heartbeat (c) of larvae at $72 \mathrm{hpf}(\mathrm{n}=3) .{ }^{*} P<0.05$

and low concentration groups $(p<0.05)$. The reason for the inhibition of body length was similar with that of hatching failure. Namely, the increase of yolk sac area shortened the body length of the larvae, indicating that the hydrolysate concentration had an important influence on the embryo's development speed [41-44].

Heart, as one of the earliest functional organs of zebrafish development, is also an important toxicological evaluation index in zebrafish embryos development. The related indexes mainly include pericardial area and $20 \mathrm{~s}$ heart rate [41, 47]. When zebrafish embryos were cultured in the hydrolysate with the concentrations of 0.75 and $0.80 \mathrm{mg} / \mathrm{mL}$, the death of the zebrafish embryos was so severe that it was impossible to measure the pericardial area and the number of heartbeats in $20 \mathrm{~s}$. Therefore, only the pericardial area and the number of heartbeats in $20 \mathrm{~s}$ of the zebrafish larvae cultivated in the concentration range of $0.45-0.70 \mathrm{mg} / \mathrm{mL}$ were counted. Figure $7 \mathrm{~b}, \mathrm{c}$ recorded the pericardial area and $20 \mathrm{~s}$ heartbeat of zebrafish larvae farmed in diverse hydrolysates at 72 hpf. When the zebrafish larvae were cultivated in $\mathrm{ACH}$ with the concentration range of $0.45-0.60 \mathrm{mg} / \mathrm{mL}$, the value of the pericardial area $(18,124 \pm 600,18,564 \pm 900$,
$18,845 \pm 800$, and $19,123 \pm 500 \mu \mathrm{m}^{2}$ for $0.45,0.50,0.55$, and $0.60 \mathrm{mg} / \mathrm{mL}$ groups, respectively) was almost the same as that of the blank group $\left(17,998 \pm 500 \mu \mathrm{m}^{2}\right)$, and there no significant differences between blank and groups of $0.45-0.60 \mathrm{mg} / \mathrm{mL}(p>0.05)$, indicating that these concentrations had almost no effect on the pericardial area of zebrafish larvae. But, the pericardial area of zebrafish larvae increased sharply when the concentration was increased to $0.65 \mathrm{mg} / \mathrm{mL}(24,536 \pm 700$ $\left.\mu \mathrm{m}^{2}\right)$ and $0.70 \mathrm{mg} / \mathrm{mL}\left(28,476 \pm 1000 \mu \mathrm{m}^{2}\right)$ compared with blank and groups of $0.45-0.60 \mathrm{mg} / \mathrm{mL}(p<0.05)$, demonstrating that high concentration groups of $\mathrm{ACH}$ $(0.65-0.70 \mathrm{mg} / \mathrm{mL})$ would make the pericardial area of zebrafish larvae bigger. In terms of two other hydrolytic products $(\mathrm{ECH}$ and $\mathrm{AECH})$, they had the similar effect on pericardial area of zebrafish larvae. Concretely, compared with blank group, low concentrations (0.45$0.65 \mathrm{mg} / \mathrm{mL}$ ) had almost no influence on the pericardial area of zebrafish larvae $(p>0.05)$, while the high concentration $(0.70 \mathrm{mg} / \mathrm{mL})$ would make the pericardial area bigger $(p<0.05)$. The $20 \mathrm{~s}$ heartbeat of zebrafish larvae was also measured and the results were shown in Fig. 7c. For the $\mathrm{ACH}$, the $20 \mathrm{~s}$ heartbeats of zebrafish embryos in 
the blank group, $0.45,0.50,0.55$, and $0.60 \mathrm{mg} / \mathrm{mL}$ groups were $37 \pm 0.7,36 \pm 0.8,37 \pm 0.6,34 \pm 0.8$, and $35 \pm 0.5$, respectively. And there was no difference in $20 \mathrm{~s}$ heartbeats of zebrafish embryos between the blank and these concentrations $(p>0.05)$. However, the $20 \mathrm{~s}$ heartbeats of zebrafish embryos in 0.65 and $0.70 \mathrm{mg} / \mathrm{mL}$ groups were only $32 \pm 0.6$ and $30 \pm 0.7$, respectively, which was much lower than that of blank and concentration groups of $0.45-0.60 \mathrm{mg} / \mathrm{mL}(p<0.05)$. This result illustrated that the ACH concentration groups of $0.65-0.70 \mathrm{mg} / \mathrm{mL}$ would slow the heartbeat of zebrafish embryos. For the $\mathrm{ECH}$, it can be concluded that there was no difference between the blank and concentration groups of 0.45$0.65 \mathrm{mg} / \mathrm{mL}(p>0.05)$, and the concentration groups of $0.65-0.70 \mathrm{mg} / \mathrm{mL}$ would adversely affect the heartbeat of zebrafish embryos $(p<0.05)$. The effect of different concentrations of AECH on the $20 \mathrm{~s}$ heartbeat of zebrafish embryos was consistent with that of $\mathrm{ACH}$. The reason for the decrease in $20 \mathrm{~s}$ heartbeat of zebrafish embryos may be due to the disease of yolk sac and cardiovascular during growth process of zebrafish embryos $[18,48]$.

In all, the mortality and hatchability of zebrafish embryos were determined to design the dosage of the collagen hydrolysates for the next experiments. The results of $\mathrm{LC}_{50}$ values showed that all the three collagen hydrolysates have the "Practically Nontoxic" property. Additionally, based on the above analysis of the growth morphology, deformity rate, body length, pericardial area and $20 \mathrm{~s}$ heartbeat of zebrafish embryos, it can be concluded that the low concentration $(\leq 0.6 \mathrm{mg} / \mathrm{mL})$ can accelerated the embryonic development process, while the growth of embryos was the opposite when they were treated with higher concentrations $(\geq 0.65 \mathrm{mg} / \mathrm{mL})$.

\subsection{General analysis of amino acid water-soluble fertilizer (AAWSF)}

AAWSF are mainly composed of various amino acids. Compared with other organic nitrogen fertilizers, they have the advantages of being easily absorbed to promote plant growth, improve crop yield, enhance the disease resistance, and possess high photosynthesis efficiency. Here, the three types of AAWSF were prepared based on the obtained three collagen hydrolysates, and their formulas were shown in Additional file 1: Table S7. Notably, all the fertilizers were used as fertigation in the crop seeding and growth process. According to the technical indicators of standards NY 1429-2010 "Water-soluble fertilizers containing amino-acids" [49] and NY 11102010 "Water-soluble fertilizers-Content-limits of mercury, arsenic, cadmium, lead and chromium" [50], the physicochemical indexes (e.g. heavy metal content, insoluble substance content and $\mathrm{pH}$ value) of the obtained AAWSF were analyzed. Table 4 showed the heavy metal
Table 4 Contents of heavy metals in different AAWSF

\begin{tabular}{lllll}
\hline $\begin{array}{l}\text { Heavy metal } \\
\text { element }\end{array}$ & Limit value & OH & M & OH-M \\
\hline $\mathrm{Cr}(\mathrm{mg} / \mathrm{kg})$ & $\leq 50$ & $8.92 \pm 0.39$ & $3.97 \pm 0.18$ & $5.21 \pm 0.22$ \\
$\mathrm{Hg}(\mathrm{mg} / \mathrm{kg})$ & $\leq 5$ & - & - & - \\
$\mathrm{As}(\mathrm{mg} / \mathrm{kg})$ & $\leq 10$ & - & - & - \\
$\mathrm{Cd}(\mathrm{mg} / \mathrm{kg})$ & $\leq 10$ & - & - & - \\
$\mathrm{Pb}(\mathrm{mg} / \mathrm{kg})$ & $\leq 50$ & - & - & - \\
\hline
\end{tabular}

"-" means not be detected

contents of each kind of fertilizer. It can be founded that the $\mathrm{Cr}$ contents of $\mathrm{OH}, \mathrm{M}$ and $\mathrm{OH}-\mathrm{M}$ nutrients, which were prepared by using the three collagen hydrolysates of $\mathrm{ACH}, \mathrm{ECH}$ and $\mathrm{AECH}$, respectively, were 8.92, 3.97 and $5.21 \mathrm{mg} / \mathrm{kg}$, respectively. All the $\mathrm{Cr}$ contents were less than the limit value in NY 1110-2010. Other heavy metals such as $\mathrm{Hg}, \mathrm{As}, \mathrm{Cd}$ and Pd had not been detected. These results indicated that these AAWSF met the standard requirement.

As well known, the insoluble substance at high content in water-soluble fertilizers will block the dripper and drip irrigation filters of the irrigation system, which will reduce work efficiency and fertilization effect [51, 52]. For this purpose, the contents of insoluble substance in $\mathrm{OH}, \mathrm{M}$ and $\mathrm{OH}-\mathrm{M}$ fertilizers were characterized using the weight method, and the results showed that there was no insoluble substance in the three types of AAWSF, meeting the NY 1429-2010 standard (limit value, $50 \mathrm{~g} / \mathrm{L}$ ). The $\mathrm{pH}$ values of $\mathrm{OH}, \mathrm{M}$ and $\mathrm{OH}-\mathrm{M}$ fertilizers were 7.82 , 7.21 and 7.84, respectively. All of these $\mathrm{pH}$ values were within the scope specified by the NY 1429-2010 standard $(\mathrm{pH}=3.0-9.0)$. So, the $\mathrm{OH}, \mathrm{M}$ and $\mathrm{OH}-\mathrm{M}$ fertilizers can be as candidates for the growth of diverse seedings.

\subsection{Effect of different AAWSF on the macroscopical growth of various seedlings}

The effect of AAWSF on the growth of seedlings was mainly evaluated by analyzing the growth morphology, germination rate, plant height and fresh leaves weight. Additional file 1: Fig. S7 displayed the visual physiognomic growth morphology of wheat on the 20th day. Additionally, Fig. 8 quantitatively recorded the germination rate (on the fifth day), plant height and fresh leaves weight of wheat on the 20th day. The germination rates in the $\mathrm{CK}, \mathrm{OF}, \mathrm{OH}, \mathrm{M}$, and $\mathrm{OH}-\mathrm{M}$ groups were $54.6 \pm 1.8$, $68.4 \pm 2.6,73.5 \pm 3.0,76.2 \pm 2.7$, and $89.4 \pm 4.1 \%$, respectively, suggesting that compared with the CK group, the AAWSF can significantly promote the germination of wheat, and especially the $\mathrm{OH}-\mathrm{M}$ had the most obvious promoting effect $(p<0.01)$. For the plant height, compared with CK, OF groups, AAWSF exhibited better promoting effect $(18.5 \pm 0.1,20.3 \pm 0.3,21.4 \pm 0.2$, 

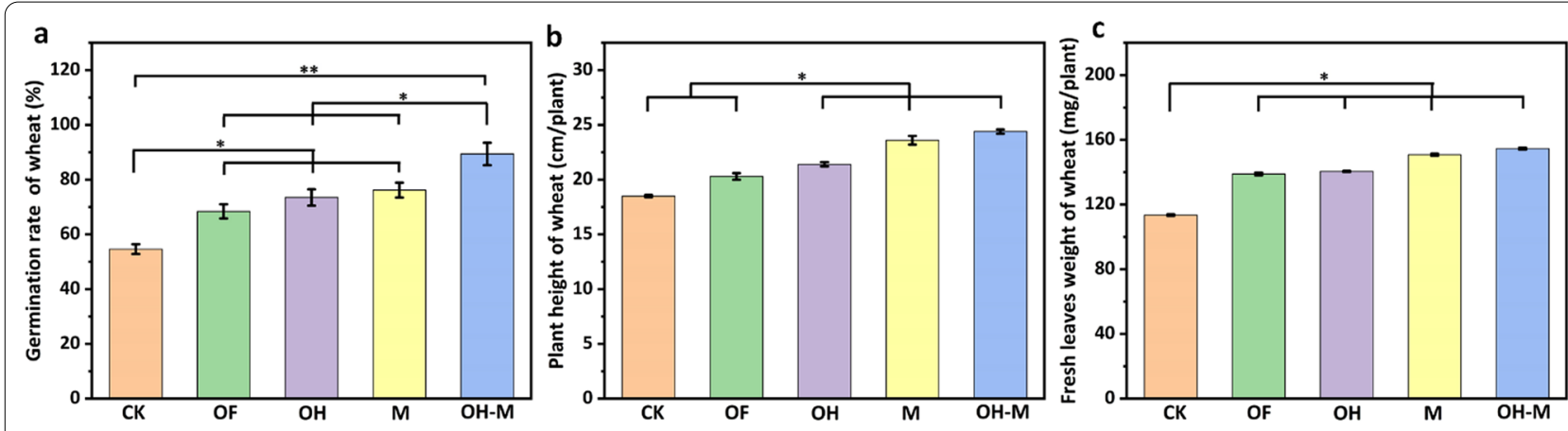

Fig. 8 Germination rate (a), plant height (b) and fresh leaves weight (c) of wheat $(n=3) .{ }^{*} P<0.05,{ }^{* *} P<0.01$
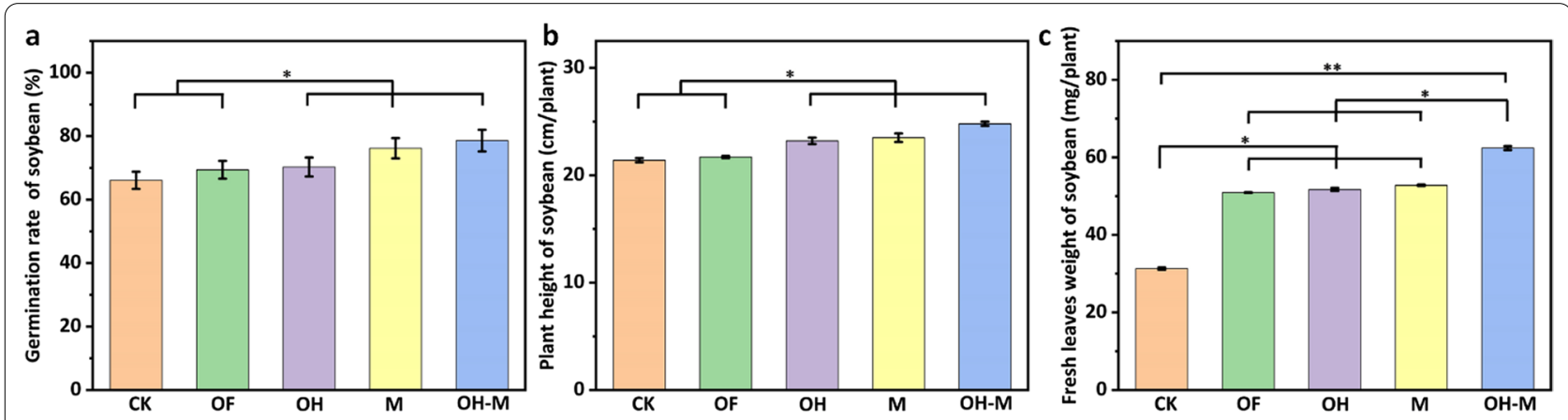

Fig. 9 Germination rate (a), plant height $(\mathbf{b})$ and fresh leaves weight $(\mathbf{c})$ of soybean $(n=3)$. ${ }^{*} P<0.05,{ }^{*} P<0.01$

$23.6 \pm 0.4$ and $24.4 \pm 0.2 \mathrm{~cm} /$ plant of $\mathrm{CK}, \mathrm{OF}, \mathrm{OH}, \mathrm{M}$, and $\mathrm{OH}-\mathrm{M}$, respectively.) $(p<0.05)$. Additionally, the fresh leaves weight in the $\mathrm{CK}, \mathrm{OF}, \mathrm{OH}, \mathrm{M}$, and $\mathrm{OH}-\mathrm{M}$ groups were $113.5 \pm 0.5,138.9 \pm 0.8,140.5 \pm 0.3,150.8 \pm 0.7$, and $154.6 \pm 0.6 \mathrm{mg} /$ plant, respectively, indicating that the AAWSF also can improve the weight of fresh leaves compared with the CK group $(p<0.05)$. Based on these results, it can be seen that the order of promoting effect on wheat was $\mathrm{OH}-\mathrm{M}>\mathrm{M}>\mathrm{OH}>\mathrm{OF}>\mathrm{CK}$, indicating that the AAWSF were more beneficial for the growth of wheat. This sequence of promoting effect also demonstrated that the smaller the MW of the collagen hydrolysate, the easier it is to be absorbed and utilized by wheat, thereby promoting their growth.

Additional file 1: Fig. S8 showed the growth morphology of soybean on the tenth day. Visually, soybean farmed with fertilizers containing $\mathrm{N}$ sources had better growth trends than CK group. And, the leaves yellowing degree of soybean cultured with OF fertilizer was serious than that watered with three AAWSF. To distinguish the difference between these groups, the germination rate, plant height and fresh leaves weight of soybeans were calculated. As depicted in Fig. 9, for the germination rate and plant height, the AAWSF has a better promoting effect on soybean (germination rate: $66.1 \pm 2.7,69.4 \pm 2.8$,
$70.3 \pm 3.0,76.4 \pm 3.2$, and $78.6 \pm 3.4 \%$, respectively. plant height: $21.4 \pm 0.2,21.7 \pm 0.1,23.2 \pm 0.3,23.5 \pm 0.4$ and $24.8 \pm 0.2 \mathrm{~cm} /$ plant of $\mathrm{CK}, \mathrm{OF}, \mathrm{OH}, \mathrm{M}$, and $\mathrm{OH}-\mathrm{M}$, respectively.) $(p<0.05)$. The fresh leaves weight in the $\mathrm{CK}, \mathrm{OF}, \mathrm{OH}, \mathrm{M}$, and $\mathrm{OH}-\mathrm{M}$ groups were $31.3 \pm 0.3$, $50.9 \pm 0.1, \quad 51.7 \pm 0.4, \quad 52.8 \pm 0.2$, and $62.4 \pm 0.5 \mathrm{mg} /$ plant, respectively, demonstrating that the AAWSF can importantly promote the fresh leaves weight of soybean, and especially the $\mathrm{OH}-\mathrm{M}$ had the most obvious promoting effect $(p<0.01)$. These results indicated that the three AAWSF fabricated by the collagen hydrolysates can accelerate the germination and growth of soybean. Moreover, among the three types of AAWSF, it can be concluded that the order of promoting effect on soybean was $\mathrm{OH}-\mathrm{M}>\mathrm{M}>\mathrm{OH}$, demonstrating that the smaller the MW of collagen hydrolysate was, the more distinct the promotion effect was.

Also, for the obvious growth of rapeseed cultured on the 20th day, it can be found that the rapeseed seeded with three AAWSF had the higher germination rates than that watered with CK and OF (Additional file 1: Fig. S9). The germination rate, plant height and fresh leaves weight were calculated to distinguish the difference in the growth of rapeseed by different fertilizers. As shown in Fig. 10, the germination rates in the $\mathrm{OH}$, 

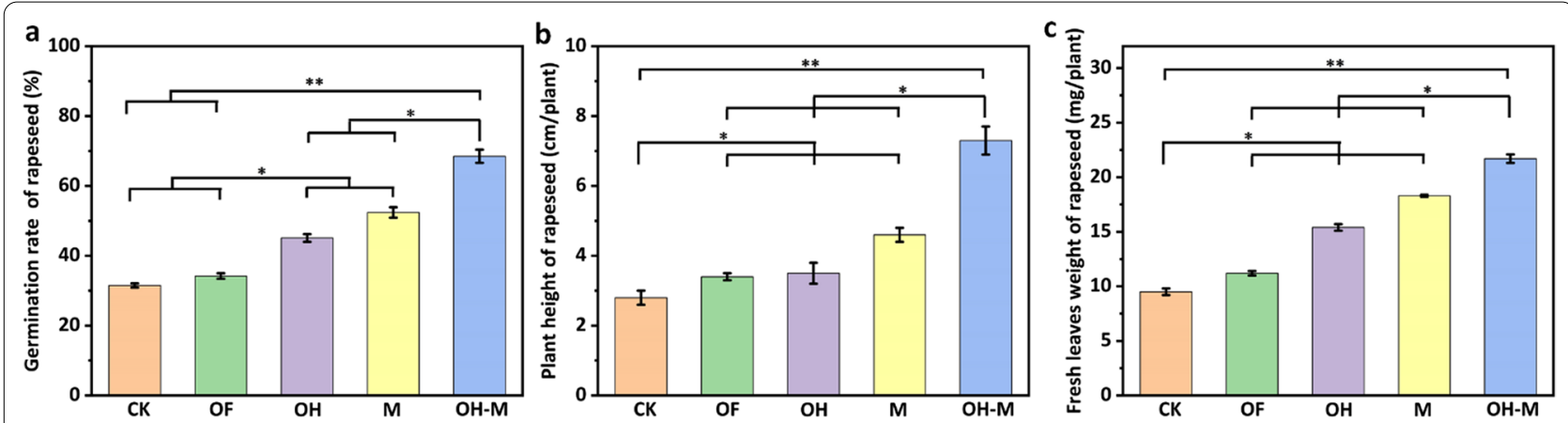

Fig. 10 Germination rate (a), plant height (b) and fresh leaves weight (c) of rapeseed $(n=3) .{ }^{*} P<0.05$, ${ }^{* *} P<0.01$

$\mathrm{M}$ and $\mathrm{OH}-\mathrm{M}$ were higher than those in the $\mathrm{CK}$ and OF groups $(31.5 \pm 0.6,34.2 \pm 0.8,45.1 \pm 1.1,52.4 \pm 1.5$ and $68.5 \pm 1.9 \%$ of $\mathrm{CK}, \mathrm{OF}, \mathrm{OH}, \mathrm{M}$, and $\mathrm{OH}-\mathrm{M}$, respectively.), showing that AAWSF had the promoting effect for the rapeseed, especially the $\mathrm{OH}-\mathrm{M}(P<0.01)$. For the plant height and fresh leaves weight, compared with CK group, AAWSF had a better promotion effect on rapeseed growth, and especially the $\mathrm{OH}-\mathrm{M}$ had the most distinct promoting effect (Plant height: $2.8 \pm 0.2$, $3.4 \pm 0.1,3.5 \pm 0.3,4.6 \pm 0.2$ and $7.3 \pm 0.4 \mathrm{~cm} /$ plant of $\mathrm{CK}, \mathrm{OF}, \mathrm{OH}, \mathrm{M}$, and $\mathrm{OH}-\mathrm{M}$, respectively. Fresh leaves weight: $9.5 \pm 0.3,11.2 \pm 0.2,15.4 \pm 0.3,18.3 \pm 0.1$ and $21.7 \pm 0.4 \mathrm{mg} /$ plant of $\mathrm{CK}, \mathrm{OF}, \mathrm{OH}, \mathrm{M}$, and $\mathrm{OH}-\mathrm{M}$, respectively.) $(p<0.01)$. Thus, the promotion effect on rapeseed was $\mathrm{OH}-\mathrm{M}>\mathrm{M}>\mathrm{OH}>\mathrm{OF}$, indicating that the AAWSF were more beneficial to the growth of rapeseed, and the AAWSF with the smaller MW was more conducive to the germination and growth of rapeseeds.

In summary, based on the development of three kinds of crops, it can be found that the seedlings fed with fertilizers containing $\mathrm{N}$ source showed better growth tendency than that watered with CK fertilizer without addition of $\mathrm{N}$ source. Among all the fertilizers containing $\mathrm{N}$ source, plants cultivated by the amino acid fertilizers exhibited more obvious growth and development advantages. Moreover, by the analysis of crop growth parameters including germination rate, plant height and fresh leaves weight, it can be seen that the order of promoting effect of AAWSF on the three crops was $\mathrm{OH}-\mathrm{M}>\mathrm{M}>\mathrm{OH}$. This is because the $\mathrm{OH}-\mathrm{M}$ fertilizer has a relatively small molecule and contains the highest content of small molecular peptides and amino acids, which are easily absorbed and converted by crops [53].

\subsection{Effect of different AAWSF on the contents of $\mathrm{Cr}, \mathrm{N}, \mathrm{P}$ and $\mathrm{K}$, chlorophyll and soluble sugar in seedlings}

The accumulation of $\mathrm{Cr}$ in wheat, soybean and rapeseed seedlings treated with different AAWSF was shown in Fig. 11a. For the wheat and soybean, the $\mathrm{Cr}$ contents in the $\mathrm{OH}$ and $\mathrm{OH}-\mathrm{M}$ groups had a slight enrichment compared with that in the $\mathrm{CK}$, OF and $\mathrm{M}$ groups (wheat: $12.5 \pm 0.8,12.7 \pm 0.6,18.4 \pm 0.7,13.2 \pm 0.8$ and $17.6 \pm 0.9 \mu \mathrm{g} / \mathrm{kg}$ of CK, OF, OH, M, and $\mathrm{OH}-\mathrm{M}$, respectively. Soybean: $9.2 \pm 0.3,8.9 \pm 0.5,14.1 \pm 0.4,10.6 \pm 0.3$ and $13.8 \pm 0.5 \mu \mathrm{g} / \mathrm{kg}$ of $\mathrm{CK}, \mathrm{OF}, \mathrm{OH}, \mathrm{M}$, and $\mathrm{OH}-\mathrm{M}$, respectively. $(p<0.05)$. For the rapeseed, the $\mathrm{Cr}$ contents in $\mathrm{OH}, \mathrm{M}$ and $\mathrm{OH}-\mathrm{M}$ were higher than those in the CK and OF groups $(18.2 \pm 0.7,18.3 \pm 0.9,26.6 \pm 1.0$, $23.4 \pm 0.8$ and $25.8 \pm 0.7 \mu \mathrm{g} / \mathrm{kg}$ of $\mathrm{CK}, \mathrm{OF}, \mathrm{OH}, \mathrm{M}$, and $\mathrm{OH}-\mathrm{M}$, respectively.) $(p<0.05)$. For the same AAWSF, the $\mathrm{Cr}$ content in the rapeseed was the largest, followed by wheat and soybeans. The difference of $\mathrm{Cr}$ content in the three seedings was properly caused by the different physiological and genetic properties of the plants themselves. Notably, although the three AAWSF had a slight enrichment effect on the $\mathrm{Cr}$ content of seedlings, these values still did not surpass the limit value in standard GB2762-2017 (grains: $1.0 \mathrm{mg} / \mathrm{kg}$, beans: $1.0 \mathrm{mg} / \mathrm{kg}$, vegetable products: $0.5 \mathrm{mg} / \mathrm{kg}$ ) [54]. And the other heavy metals $(\mathrm{Hg}, \mathrm{As}, \mathrm{Cd}$ and $\mathrm{Pb}$ ) were not monitored. Therefore, the seedlings cultivated with the three AAWSF in the early stage can meet the technical indicators for the $\mathrm{Cr}$ content in the standard (GB2762-2017).

$\mathrm{N}, \mathrm{P}$, and $\mathrm{K}$ are the three major nutrient elements in plants, which play an important role in the growth and development of plants. Among them, $\mathrm{N}$ is an essential element for photosynthesis of chlorophyll. It participates in the synthesis process of vitamins and enzymes regulating the physiological activities of plants, and occupies a primary position in the life activities of plant seedlings. $\mathrm{P}$ and $\mathrm{K}$ are mainly involved in the synthesis and decomposition of carbohydrates, and can regulate plant growth. Figure 11b-d showed the uptake and accumulation of $\mathrm{N}, \mathrm{P}$ and $\mathrm{K}$ in the leaves of wheat, soybean and rapeseed. For the wheat, the $\mathrm{N}$ contents in the $\mathrm{CK}, \mathrm{OF}$, $\mathrm{OH}, \mathrm{M}$, and $\mathrm{OH}-\mathrm{M}$ groups were $10.3 \pm 0.8,14.5 \pm 0.7$, 

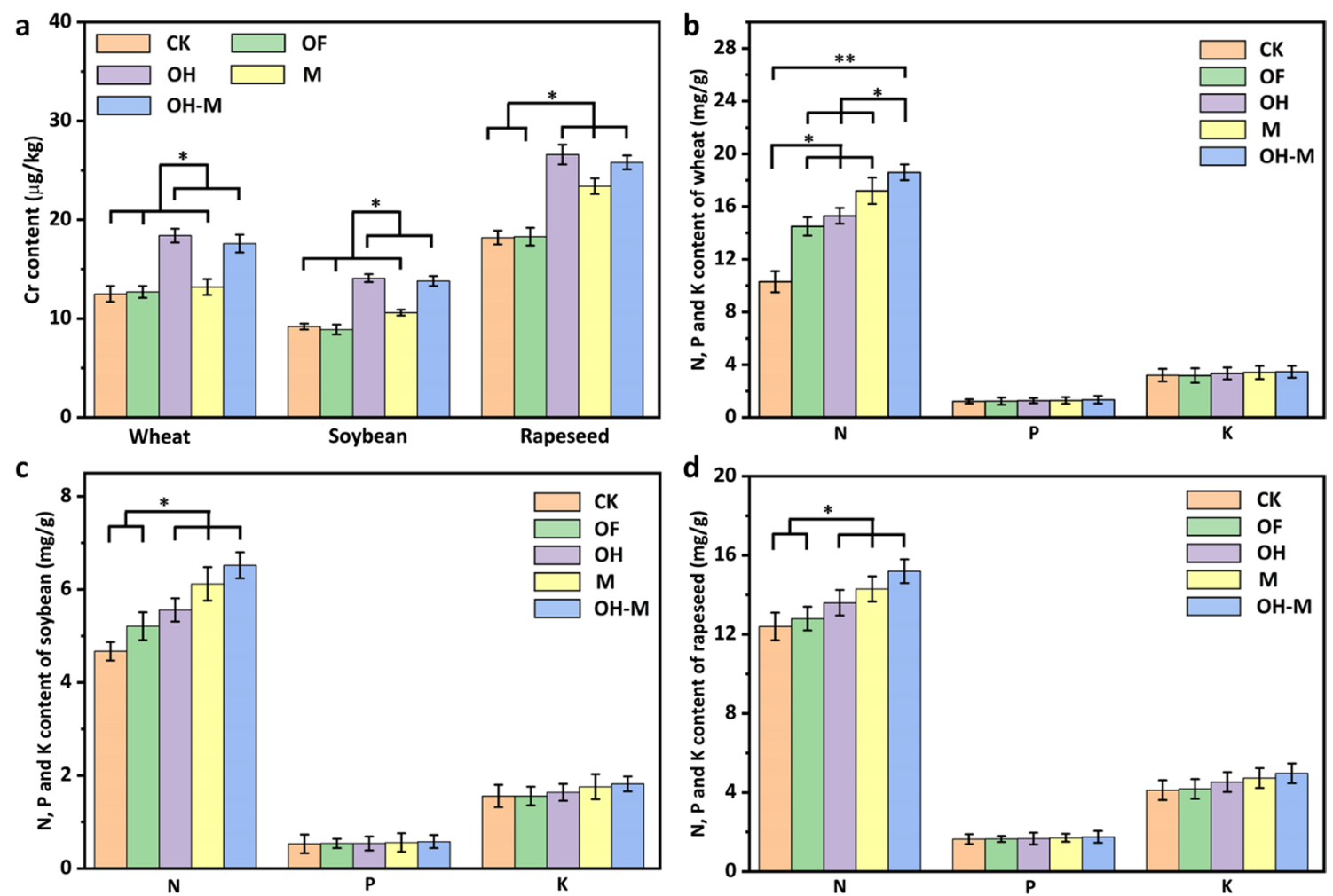

Fig. 11 a Effects of different types of AAWSF on the Cr contents in three crops. Effects of different types of AAWSF on the N, P and K contents of wheat $(\mathbf{b})$, soybean $(\mathbf{c})$ and rapeseed $(\mathbf{d})$ seedings $(n=3) .{ }^{*} p<0.05,{ }^{* *} p<0.01$

$15.3 \pm 0.6,17.2 \pm 1$, and $18.6 \pm 0.6 \mathrm{mg} / \mathrm{kg}$, respectively, suggesting that compared with the CK, the AAWSF can significantly promote the enrichment of the $\mathrm{N}$ element by the wheat, and especially the $\mathrm{OH}-\mathrm{M}$ had the most obvious effect $(p<0.01)$. For the soybean and rapeseed, compared with the CK and OF groups, AAWSF exhibited good acceleration effect for the $\mathrm{N}$ content in the seedings and higher $\mathrm{N}$ content (Soybean: 4.67 $\pm 0.2,5.21 \pm 0.3$, $5.56 \pm 0.25,6.12 \pm 0.36$ and $6.52 \pm 0.28 \mathrm{mg} / \mathrm{kg}$ of CK, OF, $\mathrm{OH}, \mathrm{M}$, and $\mathrm{OH}-\mathrm{M}$, respectively. Rapeseed: $12.4 \pm 0.7$, $12.8 \pm 0.6,13.6 \pm 0.65,14.3 \pm 0.64$, and $15.2 \pm 0.6 \mathrm{mg} / \mathrm{kg}$ of $\mathrm{CK}, \mathrm{OF}, \mathrm{OH}, \mathrm{M}$, and $\mathrm{OH}-\mathrm{M}$, respectively.) $(p<0.05)$. Notably, the $\mathrm{P}$ and $\mathrm{K}$ contents in the three seedings cultured with AAWSF were increased to different degrees compared with the CK and OF groups, but there was no difference in $\mathrm{P}$ and $\mathrm{K}$ accumulation between the five types of fertilizer $(p>0.05)$. Interestingly, the $\mathrm{N}$ content of seedlings cultivated with the same fertilizer was the highest, followed by $\mathrm{K}$ and $\mathrm{P}$ contents, which indicates that the $\mathrm{N}$ content of seedlings leaves occupied the significant status at their early growth stage. Based on these results, it can be seen that among the three types of AAWSF, the positive influence of $\mathrm{OH}-\mathrm{M}$ was the best, followed by $\mathrm{M}$ and $\mathrm{OH}$. This is properly because AAWSF can accelerate biological stimulating effect on seedlings, and the higher the content of amino acids was, the more obvious the promoting effect was $[55,56]$.

Chlorophyll plays an important role in the growth process of plants. It can not only estimate the growth performance of seedlings, but also determine the photosynthetic effect and the organic content in the seedlings. The chlorophyll contents in the three seedings were determined by the acetone method [35] and their results were shown in Fig. 12a-c and Additional file 1: Table S8. The total chlorophyll contents $\left(\mathrm{M}_{\mathrm{T}}\right)$ of wheat leaves farmed with $\mathrm{OH}(1.11 \pm 0.06 \mathrm{mg} / \mathrm{g}), \mathrm{M}$ $(1.17 \pm 0.05 \mathrm{mg} / \mathrm{g})$ and $\mathrm{OH}-\mathrm{M}(1.25 \pm 0.06 \mathrm{mg} / \mathrm{g})$ were bigger than those cultured with CK $(1.03 \pm 0.07 \mathrm{mg} / \mathrm{g})$ and OF $(1.07 \pm 0.08 \mathrm{mg} / \mathrm{g})(p<0.05)$. Additionally, the ratio of chlorophyll a and chlorophyll $b\left(\mathrm{R}_{\mathrm{a} / \mathrm{b}}\right)$ can reflect the light utilization capacity of plants. The $R_{a / b}$ values of wheat cultivated with $\mathrm{OH}(2.26), \mathrm{M}(2.34)$ and $\mathrm{OH}-\mathrm{M}$ (2.38) were also slightly higher than that cultured with CK (2.22) and OF (2.24), illustrating that wheat cultured with AAWSF had greater photosynthetic capacity compared with the other treatments. And among them, the photosynthetic capacity of wheat cultivated with $\mathrm{OH}-\mathrm{M}$ was the strongest. Similarly, compared with the CK, 

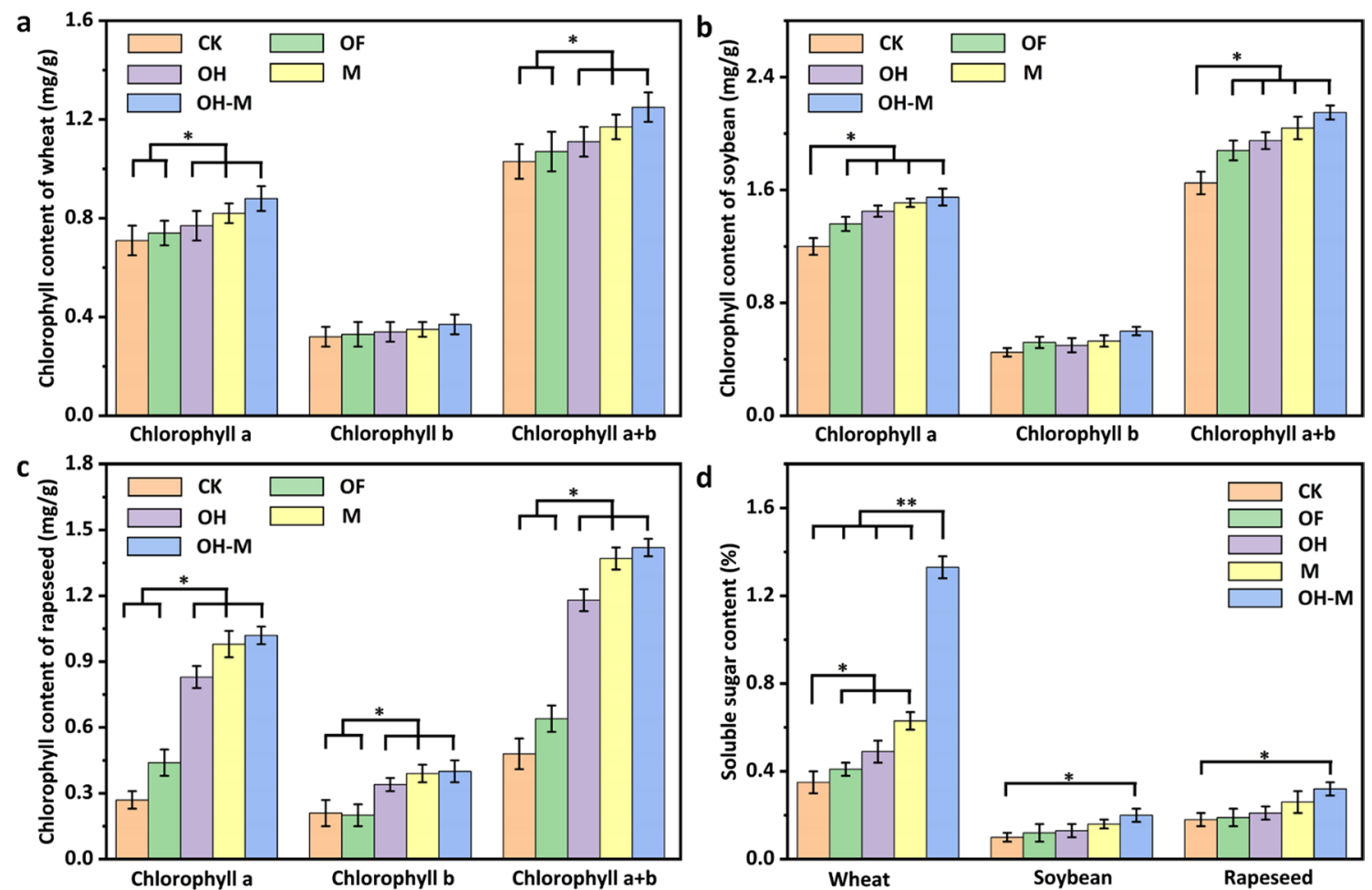

Fig. 12 Effects of different types of AAWSF on the chlorophyll contents in wheat (a), soybean $(\mathbf{b})$ and rapeseed $(\mathbf{c})$ seedlings $(n=3)$. (d) Effects of different types of AAWSF on the soluble sugar contents in the leaves of seedlings $(n=3) .{ }^{*} p<0.05,{ }^{* *} p<0.01$

the total chlorophyll contents in soybean and rapeseed were also higher when they were applied with AAWSF $(p<0.05)$. Moreover, the results of $\mathrm{R}_{\mathrm{a} / \mathrm{b}}$ for soybean and rapeseed $\left(\mathrm{R}_{\mathrm{a} / \mathrm{b}}\right.$ of soybean watered with $\mathrm{CK}, \mathrm{OF}, \mathrm{OH}, \mathrm{M}$ and $\mathrm{OH}-\mathrm{M}$ groups were $2.44,2.51,2.82,2.85$ and 2.89, respectively. $\mathrm{R}_{\mathrm{a} / \mathrm{b}}$ of rapeseed cultured with $\mathrm{CK}, \mathrm{OF}, \mathrm{OH}$, $\mathrm{M}$ and $\mathrm{OH}-\mathrm{M}$ groups were $1.29,2.2,2.44,2.52$ and 2.55, respectively) indicated that the AAWSF can accelerate the synthesis of chlorophyll and improve the photosynthetic efficiency compared with CK and OF groups, and the promoting effect of $\mathrm{OH}-\mathrm{M}$ was the best. This is because there are a large number of small molecular peptides and amino acids in $\mathrm{OH}-\mathrm{M}$ fertilizer that can be directly absorbed by seedlings and accelerate the synthesis of chlorophyll in leaves [53]. Furthermore, by analyzing $R_{a / b}$ values of each seedling, it can be inferred that the soybean farmed with AAWSF had the best photosynthetic ability, followed by rapeseed and wheat, which was properly taken into account by the difference of crop category.

Soluble sugar is an important carbohydrate in plant seedlings, which provides energy for the growth of seedlings. It not only reflects the growth performance and quality of seedlings, but also shows the resistance of seedlings to the environment. The soluble sugar content in the seedlings leaves was determined by using the anthrone colorimetry [35] (the principle was seen in Additional file 1: Fig. S10). According to the standard curve of soluble sugar content (Additional file 1: Fig. S11), the soluble sugar content of seedings was calculated. As shown in Fig. 12d, compared with the CK, the soluble sugar contents in the wheat leaves cultivated with $\mathrm{OF}, \mathrm{OH}, \mathrm{M}$ and $\mathrm{OH}-\mathrm{M}$ showed an increase to some extent, and the largest soluble sugar content $(1.33 \pm 0.05 \%, p<0.01)$ was present in the $\mathrm{OH}-\mathrm{M}$ group, while the $\mathrm{OF}, \mathrm{OH}, \mathrm{M}$ groups showed the slightly higher soluble sugar contents than the CK group $(p<0.05)$, indicating that the AAWAF possessed a higher effect for enhancing the enrichment of soluble sugar content. For the soybean and rapeseed, the $\mathrm{OH}-\mathrm{M}$ group displayed a difference with the $\mathrm{CK}$ group $(p<0.05)$. This is because of the presence of the smaller MW peptides and amino acids in $\mathrm{OH}-\mathrm{M}$ that can be easily absorbed by the seedlings y[54], resulting in the improvement of soluble sugar content in the seedings.

In all, compared with the CK and OF, the three AAWSF had a better promoting effect on the growth of three kinds of crops. Meanwhile, the positively promotion effect of AAWSF was also applicable to various categories of crops. Among the three AAWSF, the $\mathrm{OH}-\mathrm{M}$ with the smallest MW had the most obvious promoting effect 
on crops. In a word, based on all the results of protein content in three collagen hydrolysates and plants growth of the tested crops, the alkaline-enzymatic hydrolysis method is the best treatment method for CS.

\section{Conclusions}

In summary, three types of collagen hydrolysates with different MW (ACH, ECH and $\mathrm{AECH}$ ) were successfully extracted from CS. By using these three collagen hydrolysates as nutrient solutions, the toxicity of three collagen hydrolysates was evaluated based on zebrafish embryos. Briefly, the hatchability, mortality, deformity, body length, pericardial area and $20 \mathrm{~s}$ heartbeats of zebrafish embryos were recorded at different exposure time. The results of toxicity tests indicated that three collagen hydrolysates with low concentrations (less than $0.6 \mathrm{mg} / \mathrm{mL}$ ) were relatively safe for the cultivation of zebrafish embryos. The three collagen hydrolysates presented the characteristic of "Practically Nontoxic". Subsequently, ACH, ECH and $\mathrm{AECH}$ mainly containing amino acid were used to formulate various AAWSF $(\mathrm{OH}, \mathrm{M}$ and $\mathrm{OH}-\mathrm{M})$ for the growth of various categories of seedlings including wheat, soybean and rapeseed. Notably, the $\mathrm{Cr}$ contents in the all AAWSF were less than $10 \mathrm{mg} / \mathrm{kg}$, which is far less than the limit value in the standard $(50 \mathrm{mg} / \mathrm{kg})$. The effects of AAWSF on the growth and development of seedlings were also investigated. For the germination rate, plant height, fresh leaves weight, the three AAWSF had obvious promotion effect, especially for the $\mathrm{OH}-\mathrm{M}$. Compared with OF, the germination rate, plant height and fresh leaves weight of wheat in the $\mathrm{OH}-\mathrm{M}$ group were increased by $21 \%, 4.1 \mathrm{~cm}$ and $15.7 \mathrm{mg}$, respectively; the germination rate, plant height and fresh leaves weight of soybean in the $\mathrm{OH}-\mathrm{M}$ group were increased $9.2 \%, 3.1 \mathrm{~cm}$ and $11.5 \mathrm{mg}$, respectively; the germination rate, plant height and fresh leaves weight of rapeseed in the $\mathrm{OH}-\mathrm{M}$ group were increased $34.3 \%, 3.9 \mathrm{~cm}$ and $10.5 \mathrm{mg}$, respectively. For the N, soluble sugar and chlorophyll contents, the three AAWSF also had significant promotion effect in the early stage. Compared with OF, the $\mathrm{N}$ contents of wheat, soybean and rapeseed in $\mathrm{OH}-\mathrm{M}$ groups were increased by $4.1,1.31$ and $2.4 \mathrm{mg}$, respectively; the total chlorophyll contents of wheat, soybean and rapeseed in $\mathrm{OH}-\mathrm{M}$ groups were increased by $0.18,0.42$ and $0.78 \mathrm{mg}$, respectively; the soluble sugar contents of wheat, soybean and rapeseed in $\mathrm{OH}-\mathrm{M}$ groups were increased by 0.92 , 0.08 and $0.13 \%$, respectively. These results exhibited that the $\mathrm{OH}-\mathrm{M}$ had the best promoting effect on the growth and development of seedlings, followed by $\mathrm{M}$ and $\mathrm{OH}$. In all, based on all the results of protein contents in three collagen hydrolysates and the growth of the tested crops, the alkaline-enzymatic hydrolysis method was the best treatment method for CS. In a word, this work showed that collagen hydrolysate derived from CS has a great potential to be utilized as nitrogen source in the preparation of AAWSF for crop growth.

\begin{abstract}
Abbreviations
AAWSF: Amino acid water-soluble fertilizer; ACH: Alkaline collagen hydrolysate; AECH: Alkaline-enzymatic collagen hydrolysate; As: Arsenic; Cd: Cadmium; CS: Chrome shavings; ECH: Enzymatic collagen hydrolysate; GPC: Gel permeation chromatography; Hg: Mercury; hpf: Hours post-fertilization; Hyp: Hydroxyproline; ICP: Inductively coupled plasma emission spectroscopy; K: Potassium; $\mathrm{LC}_{50}$ : Medial lethal concentration; M: Enzymatic type fertilizer; MW: Molecular weight; N: Nitrogen; OECD: Organization for Economic Co-operation and Development; $\mathrm{OH}$ : Alkaline type fertilizer; $\mathrm{OH}-\mathrm{M}$ : Alkaline-enzymatic type fertilizer; P: Phosphorus; Pb: Plumbum; SDS-PAGE: Sodium dodecyl sulphatepolyacrylamide gel electrophoresis.
\end{abstract}

\section{Supplementary Information}

The online version contains supplementary material available at https://doi. org/10.1186/s42825-021-00072-1.

\begin{abstract}
Additional file 1. Fig. S1. Standard curve of Hyp. Table S1. Details of the orthogonal design for alkaline hydrolysis procedure. Table S2. Orthogonal experiments of alkaline hydrolysis method and the corresponding results. Fig. S2. Effect of $\mathrm{NaOH}(\mathbf{a})$, temperature (b) and time (c) on Hyp content of protein hydrolysate. Table S3. Details of the orthogonal design for enzymatic hydrolysis procedure. Table S4. Orthogonal experiments of enzymatic hydrolysis method and the corresponding consequences. Fig. S3. Effect of 1398 neutral protease (a), time (b) and temperature (c) on Hyp content of protein hydrolysates. Table S5. Toxicity results of different collagen hydrolysate. Table S6. Acute Toxicity Rating Scale by Fish and Wildlife Service. Fig. S4. Images of morphological development of zebrafish embryos treated with ACH. Fig. S5. Images of morphological development of zebrafish embryos treated with ECH. Fig. S6. Images of morphological development of zebrafish embryos treated with $\mathrm{AECH}$. Table S7. Nutrient input of various fertilizers. Fig. S7. Growth morphology of wheat on the 20th day. Fig. S8. Visible growth morphology of soybean on the tenth day. Fig. S9. Visible growth morphology of rapeseed on the 20th day. Table S8. Effects of different amino acid fertilizer on chlorophyll content in seedings leaves. Fig. S10. Principle of determination of soluble sugar by anthranone method. Fig. S11. Standard curve of soluble sugar content.
\end{abstract}

\section{Acknowledgements}

The authors thank Jinwei Zhang (College of Biomass Science and Engineering, Sichuan University) for his help in the amino acid analysis

\section{Authors' contributions}

Li Zhao performed all the experiments and was a major contributor in data analyses and writing of this manuscript. Shengdong Mu made substantial contributions to the design and implement of the experiments in this work. Weixiang Wang made important contributions to the design and result analysis of zebrafish toxicity experiments. Haibin Gu is the superior of this work and made great contribution to the conception of the study, the discussion of the results and the revision of the manuscript. All authors read and approved the final manuscript.

\section{Authors' information}

Not applicable.

\section{Funding}

Financial support from the Science \& Technology Department of Sichuan Province (No. 2018HH0038) is gratefully acknowledged.

Availability of data and materials

All the data needed to evaluate the conclusions in the paper are present in the paper and the supplementary material. 


\section{Declarations}

\section{Competing interests}

The authors declare that they have no competing interests.

\section{Author details}

${ }^{1}$ Key Laboratory of Leather Chemistry and Engineering of Ministry of Education, Sichuan University, Chengdu 610065, China. ${ }^{2}$ National Engineering Research Center of Clean Technology in Leather Industry, Sichuan University, Chengdu 610065, China. ${ }^{3}$ College of Food and Bioengineering, Xihua University, Chengdu 610039, China.

Received: 19 March 2021 Accepted: 10 November 2021

Published online: 15 January 2022

\section{References}

1. Kupec J, Dvorackova M, Rudlova S, Ruzicka J, Kolomaznik K. Deproteination of chrome waste by washing and enzymatic hydrolysis. J Am Leather Chem Assoc. 2002;97(9):349-54.

2. Fathima A, Aravindhan R, Rao JR, Nair BU. Biomass of Termitomyces clypeatus for chromium(III) removal from chrome tanning wastewater. Clean Technol Environ Policy. 2015:17(2):541-7.

3. Ocak B. Film-forming ability of collagen hydrolysate extracted from leather solid wastes with chitosan. Environ Sci Pollut Res. 2018;25(1):4643-55.

4. Rao JR, Thanikaivelan P, Sreeram KJ, Nair BU. Green route for the utilization of chrome shavings (chromium-containing solid waste) in tanning industry. Environ Sci Technol. 2002;36(6):1372-6.

5. Brown EM, Taylor MM, Marmer WN. Production and potential uses of co-products from solid tannery waste. J Am Leather Chem Assoc. 1996:91(10):270-6.

6. Sasia AA, Sang P, Onyuka A. Recovery of collagen hydrolysate from chrome leather shaving tannery waste through two-step hydrolysis using magnesium oxide and bating enzyme. J Soc Leather Technol Chem. 2019;103(2):80-4.

7. Luo FX. Resource utilization of chromium containing leather waste. West Leather. 2014:36(04):28-31.

8. Mu CD, Lin W, Zhang MR, Zhu QD. Towards zero discharge of chromiumcontaining leather waste through improved alkali hydrolysis. Waste Manag. 2003;23(9):835-43

9. Wang $Y L$, Huang XC. Dechroming method of leather shavings. China Leather. 1991:20(12):7-11.

10. Rai AK, Nived C, Sakhare PZ, Suresh PV, Bhaskar N, Mahendrakar NS. Optimization of acid hydrolysis conditions of delimed tannery fleshings by response surface method. J Sci Ind Res. 2009;68(11):967-74.

11. Liang WW, Wang ZJ, Du F. Extraction of collagen hydrolysate from leather meal by alkaline hydrolysis and its enhancement performance to paper. Pap Sci Technol. 2010;29(5):39-41.

12. Chi YL, Cui M, Cui XJ, Zhang WH, Liao XP, Shi B. Enzymatic hydrolysis of skin shavings for preparation of collagen hydrolysates with specified molecular weight distribution. J Soc Leather Technol Chem. 2012;96(1):16-20.

13. Hu Y, Liu L, Dan WH, Lin H, Dan NH. Study on the acid-enzyme combination method applied to the dechroming of chrome-tanned leather scraps. Leather Sci Eng. 2010;20(6):47-51.

14. Ding W, Liao XP, Zhang WH, Shi B. Dechroming of chromium-containing leather waste with low hydrolysis degree of collagen. J Soc Leather Technol Chem. 2015;99(3):129-33.

15. Barbazuk WB, Korf I, Kadavi C, Heyen J, Tate S, Wun E, Bedell JA, McPherson JD, Johnson SL. The syntenic relationship of the zebrafish and human genomes. Genome Res. 2000;10(9):1351-8.

16. Pei DS, Strauss PR. Zebrafish as a model system to study DNA damage and repair. Mutat Res-Fundam Mol Mech Mutagen. 2013;743:151-9.

17. Wang Z, Pu YZ, Chen YJ, Li CJ, Wang LX, Li Q, Huang CQ, Zhang ZZ, Zhang YG, Zhao BQ. Influence of dichlorvos on zebrafish behavior. J Int Pharm Res. 2013:40(3):327-30.
18. Li AJ, Zhang YR, Xia XM, Wang BR, Wamg WX. Acute toxic effect of ethanol on embryo development of Zebrafish. J Xihua Univ (Nat Sci Ed). 2019:38(6):27-31.

19. Epure DG, Cioineag CF, Becheritu M, Gaidau C, Stepan E, Gidea M. Use of biofertilizant based on collagen hydrolysate for cereal seed treatment. Agrolife Sci J. 2018;7(1):48-55.

20. Liu N, Gao LF, Ding ZW, Cheng ZP. Preparation of amino acid fertilizer with chrome shavings. China Leather. 2015;44(17):27-31.

21. Zhang Y, Dong SH. Studies of the scavenging capacity of amino acids on active oxygen radicals. Bull Sci Technol. 1997;13(5):312-5.

22. Haghighi M, Fang P, Pessarakli M. Effects of ammonium nitrate and monosodium glutamate in waste water on the growth, antioxidant activity, and nitrogen assimilation of lettuce (Lactuca sativa L.). J Plant Nutr. 2015:38(14):2217-29.

23. Bahari A, Pirdashti $H$, Yaghubi $M$. The effects of amino acid fertilizers spraying on photosynthetic pigments and antioxidant enzymes of wheat (Triticum aestivum L.) under salinity stress. Int J Agron Plant Prod. 2013:4(4):787-93.

24. Ghasemi S, Khoshgoftarmanesh AH, Afyuni M, Hadadzadeh H. Iron(II)amino acid chelates alleviate salt-stress induced oxidative damages on tomato grown in nutrient solution culture. Sci Hortic. 2014;165:91-8.

25. Cao XY, Tang L, Li BJ, Cheng Y, Nie Y, Liu DH. Effect of amino acid chelated middle-micro element fertilizer on quality of grape. Chin J Soil Sci. 2009;40(4):880-3.

26. Cheng XH, Feng XX, Zhang ZP, Sheng M, Wang LJ. Effects of "Al strong" amino-acid fertilizer on photosynthetic efficiency and yield of strawberry in plastic tunnels. J Fruit Sci. 2012;29(5):883-9.

27. Xie L, Cheng XH, Feng XX, Yang T, Zhang ZP, Wang LJ. Effects of an amino acid fertilizer on the leaf photosynthesis and fruit quality of 'Summer Black' grape. J Nanjing Agric Univ. 2013;36(2):31-7.

28. Duan CH, Shen M, Zhang ZP, Zhang C, Sun LC, Ruan SC, Wang LJ. Effects of amino-acid fertilizer on leaf photosynthesis and yield of soybean. J Nanjing Agric Univ. 2012;35(4):15-20.

29. Pang QY, Xuan YL, Cai X, Wang YG, Wang KY. Effect of cottonseed amino acid fertilizer on yield and growth of wheat. Agric Res Arid Areas. 2017;35(2):21-4

30. Tian ZH, Wang Y, Wang H, Zhang K. Regeneration of native collagen from hazardous waste: chrome-tanned leather shavings by acid method. Environ Sci Pollut Res. 2020;27(25):31300-10.

31. TG236, Fish Embryo Acute Toxicity (FET) Test, OECD guidelines for the testing of chemicals section 2. 2013.

32. NY/T 1973-2010, Water-soluble fertilizers-determination of water insoluble matter content and PH. 2010.

33. NY/T 2017-2011, Determination of nitrogen, phosphorus and potassium in plants. 2011

34. Lu RK. Methods of soil agricultural chemical analysis. Beijing: China Agricultural Science and Technology Press; 2000

35. Wang XK, Huang JL. Principles and techniques of plant physiological biochemical experiment. Beijing: Higher Education Press; 2015.

36. Etherington DJ, Sims TJ. Detection and estimation of collagen. J Sci Food Agric. 1981;32(6):539-46.

37. Wang XZ, Wen HT, Liang YX, Yang YQ, Wang KY, Dan WH. Extracting collagen from chrome shavings using alkali and protease. West Leather. 2018;40(3):41-5.

38. Chen WY, Gu HB, Qin T, Shi B. Hydrolysis of chrome shavings with a neutral protease. China Leather. 2001;30(21):2-5.

39. Brown EM, Farrell HM, Wildermuth RJ. Influence of neutral salts on the hydrothermal stability of acid-soluble collagen. J Protein Chem. 2000;19(2):85-92.

40. Rania HJ, Hassan HMM, Afify AS. Evaluation of antioxidant and metal chelating activities of protein hydrolysates produced from leather waste by alkaline and enzymatic hydrolysis. Res J Pharm Biol Chem Sci. 2016;7(4):910-9.

41. Wang WX, Wang BR, Liu ZH, Xia XM. Developmental toxicity and alteration of gene expression in zebrafish embryo exposed to 6-benzylaminopurine. Chemosphere. 2019:233:336-46.

42. Babayigit A, Thanh DD, Ethirajan A, Manca J, Muller M, Boyen HG, Conings $\mathrm{B}$. Assessing the toxicity of $\mathrm{Pb}$ - and $\mathrm{Sn}$-based perovskite solar cells in model organism Danio rerio. Sci Rep. 2016;6:18721. 
43. Almond KM, Trombetta LD. The effects of copper pyrithione, an antifouling agent, on developing zebrafish embryos. Ecotoxicology. 2016;25(2):389-98.

44. Haendel MA, Tilton F, Bailey GS, Tanguay RL. Developmental toxicity of the dithiocarbamate pesticide sodium metam in zebrafish. Toxicol Sci. 2004;81(2):390-400.

45. Kimmel CB, Ballard WW, Kimmel SR, Ullmann B, Schilling TF. Stages of embryonic development of the zebrafish. Dev Dyn. 1995;203(3):253-310.

46. Lu J, Wang ZY, Yuan YT, Xu B, Gao YL, Zhang B, Zheng QS, Wang ZH. Developmental toxicity of cadmium chloride to zebrafish embryo. Asian J Ecotoxicol. 2013;8(3):381-8.

47. Sun HJ, Zhang Y, Zhang JY, Lin HJ, Chen JR, Hong HC. The toxicity of 2,6-dichlorobenzoquinone on the early life stage of zebrafish: a survey on the endpoints at developmental toxicity, oxidative stress, genotoxicity and cytotoxicity. Environ Pollut. 2019;245:719-24.

48. Schwetz BA, Smith FA, Staples RE. Teratogenic potential of ethanol in mice, rats and rabbits. Teratology. 1978;18(3):385-92.

49. NY 1429-2010, Water-soluble fertilizers containing amino-acids. 2010.

50. NY 1110-2010, Water-soluble fertilizers-Content-limits of mercury, arsenic, cadmium, lead and chromium. 2010

51. Fu CL, Miao ZY, Han Y, Wang JM, Xu JG, Yu ZL. Formation mechanism of water-insoluble substances in water-soluble fertilizer containing N, P, K. Phosphate Compd Fertil. 2017;32(8):38-41.

52. Tu PF, Deng LS, Gong L, Hu KW, Ye QQ, Zhang CL. Effects of water-insoluble substance content in water-soluble fertilizers on the filter clogging in fertigation system. Phosphate Compd Fertil. 2012;27(1):72-3.

53. Huang JC, Peng ZP, Tu YT, Wu XN, Liu JF. Effects of amino acids fertilizer on yield and quality of broccoli. Chin Agric Sci Bull. 2018;34(34):42-6.

54. GB2762-2017, Limits of contaminants in food. 2017.

55. Calvo P, Nelson L, Kloepper JW. Agricultural uses of plant biostimulants. Plant Soil. 2014;383(1-2):3-41.

56. Chen ZY, Chen TP, Li HJ, Cui XY. Research progress in molecular mechanism of amino acids absorption and transport by plants. Mol Plant Breed. 2017;15(12):5166-71.

\section{Publisher's Note}

Springer Nature remains neutral with regard to jurisdictional claims in published maps and institutional affiliations.

\section{Submit your manuscript to a SpringerOpen ${ }^{\circ}$ journal and benefit from:}

- Convenient online submission

- Rigorous peer review

- Open access: articles freely available online

- High visibility within the field

- Retaining the copyright to your article 